\title{
De verborgen dimensie van de klimaatcrisis
}

Citation for published version (APA):

Verkerk, M. (2019). De verborgen dimensie van de klimaatcrisis: Religie, duurzaamheid en inclusie - een pleidooi voor het heilige. Maastricht University. https://doi.org/10.26481/spe.20191004mv

Document status and date:

Published: 04/10/2019

DOI:

10.26481/spe.20191004mv

Document Version:

Publisher's PDF, also known as Version of record

\section{Please check the document version of this publication:}

- A submitted manuscript is the version of the article upon submission and before peer-review. There can be important differences between the submitted version and the official published version of record.

People interested in the research are advised to contact the author for the final version of the publication, or visit the DOI to the publisher's website.

- The final author version and the galley proof are versions of the publication after peer review.

- The final published version features the final layout of the paper including the volume, issue and page numbers.

Link to publication

\footnotetext{
General rights rights.

- You may freely distribute the URL identifying the publication in the public portal. please follow below link for the End User Agreement:

www.umlib.nl/taverne-license

Take down policy

If you believe that this document breaches copyright please contact us at:

repository@maastrichtuniversity.nl

providing details and we will investigate your claim.
}

Copyright and moral rights for the publications made accessible in the public portal are retained by the authors and/or other copyright owners and it is a condition of accessing publications that users recognise and abide by the legal requirements associated with these

- Users may download and print one copy of any publication from the public portal for the purpose of private study or research.

- You may not further distribute the material or use it for any profit-making activity or commercial gain

If the publication is distributed under the terms of Article $25 \mathrm{fa}$ of the Dutch Copyright Act, indicated by the "Taverne" license above, 


\section{Maastricht University}

Afscheidsrede

\section{Prof. Dr. Maarten J. Verkerk}

Faculty of Arts and Social Sciences

\section{De verborgen dimensie van de klimaatcrisis}

Religie, duurzaamheid en inclusie - een pleidooi voor het heilige

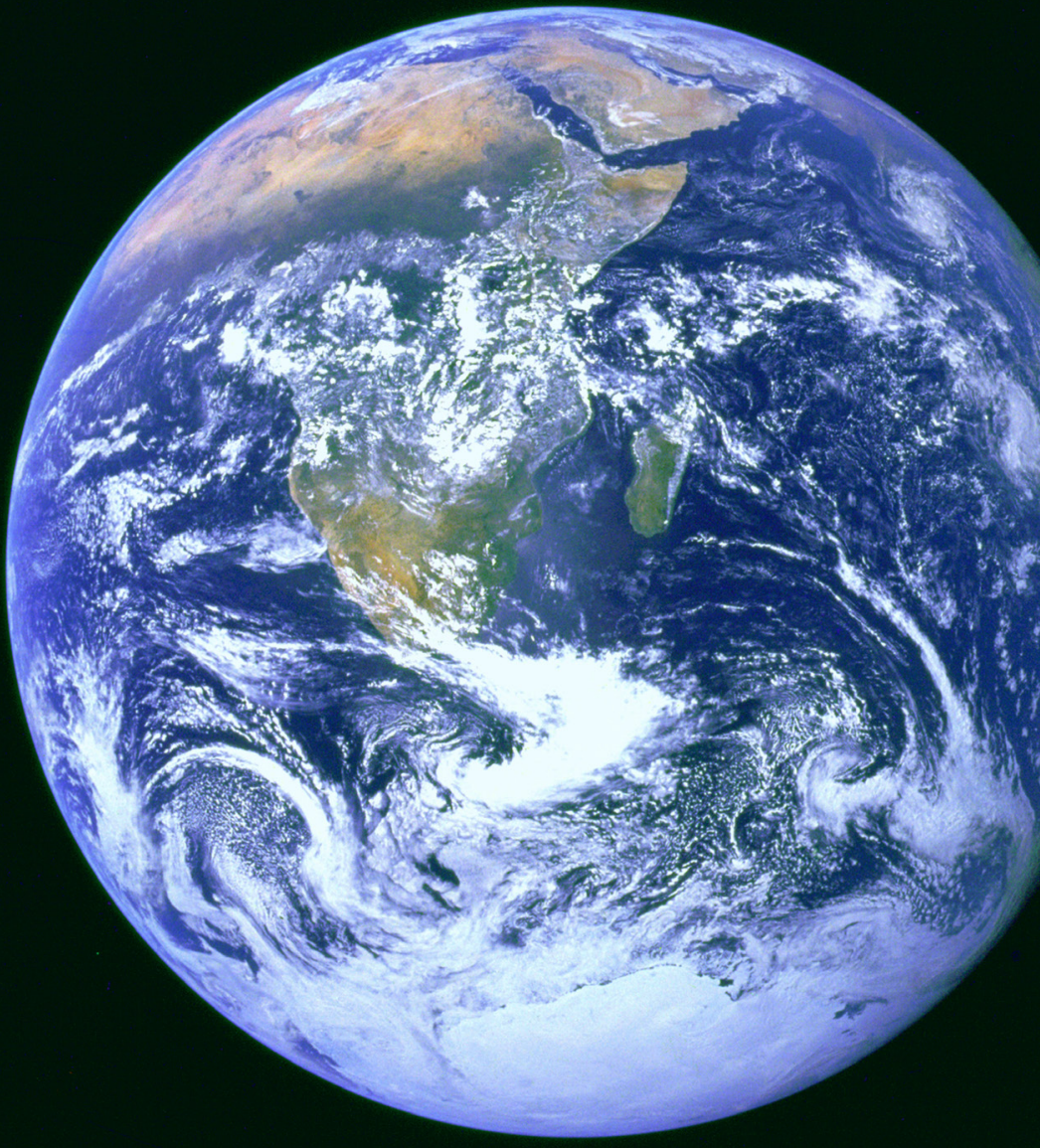




\section{De verborgen dimensie van de klimaatcrisis}

Religie, duurzaamheid en inclusie een pleidooi voor het heilige 


\section{Colofon}

Foto omslag: De foto is gemaakt door de bemanning van de Apollo 17.

Ontwerp en print: Canon The Creative Hub

ISBN: 978-90-5681-482-3

NUR: 705

( $)$ Niets uit deze uitgave mag worden verveelvoudigd, opgeslagen in een geautomatiseerd bestand of openbaar gemaakt door middel van druk, fotokopie, microfilm of op welke andere wijze dan ook zonder voorafgaande schriftelijke toestemming van de uitgever. 


\section{De verborgen dimensie van de klimaatcrisis}

Religie, duurzaamheid en inclusie een pleidooi voor het heilige

Afscheidsrede

Maastricht, 4 oktober 2019

door Prof. Dr. Maarten J. Verkerk 
'In one or two hundred years, crisscrossed by railways and steamships, covered with factories and workshops, the world will emit billions of cubic meters of carbonic acid and carbon oxide, and since the forests will have been destroyed, these hundreds of billions of carbonic acid and carbon oxide may indeed disturb the harmony of the world' (Eugene Huzar, 1857)

Mevrouw de Rector Magnificus (Maastricht), Meneer de Rector Magnificus (Eindhoven), Leden van de Colleges van Bestuur, Bestuur en curatoren van de Stichting voor Christelijke Filosofie, Collegae hoogleraren en andere leden van de universitaire gemeenschap, Familie en vrienden.

Graham Greene begint zijn boek Het einde van het spel op een merkwaardige wijze. Hij schrijft: 'Een verhaal heeft geen begin of eind: willekeurig kiest men uit zijn herinnering dat ogenblik vanwaar men terugziet of vanwaar men vooruitziet. Ik zeg "kiest men" met de lichtvaardige trots van een beroepsschrijver die - de weinige keren dat er serieus aandacht aan hem is besteed - is geprezen om zijn technische vaardigheid, maar kies ik inderdaad uit vrije wil die donkere natte januari-avond in het Park, in 1946, de aanblik van Henry Miles die zich voorovergebogen een weg baant door de stomende regen, of hebben deze beelden mij gekozen?'

Een intrigerende vraag. Kiest een schrijver een beeld of kiest het beeld de schrijver? We zijn geneigd om voor de eerste optie te gaan: mensen kiezen uit vrije wil een beeld? Maar zou het ook kunnen zijn dat het beeld een mens kiest? Ik kom aan het einde van mijn afscheidsrede op deze vraag terug.

\section{Levensgrote dilemma's}

De klimaatproblematiek is omgeven door levensgrote dilemma's. Aan de ene kant laten de rapporten van de IPCC duidelijk zien dat deze problematiekveroorzaaktwordtdoor menselijkhandelenen datdrastische maatregelen nodig zijn om de opwarming van de aarde te beperken. Deze

1 Geciteerd uit Bonneuil \& Fressoz (2017, p. xii). 
conclusies worden breed gedeeld binnen de universitaire gemeenschap. Aan de andere kant lijkt het draagvlak voor een actief klimaatbeleid bij delen van de bevolking af te nemen, komen er populistische partijen op die ontkennen dat klimaatverandering veroorzaakt wordt door menselijk handelen of die het bestaan van de klimaatverandering volledig ontkennen, en heeft Amerika zich teruggetrokken uit de akkoorden van Parijs (2015). De klimaatproblematiek - we kunnen beter spreken over de klimaatcrisis - is zo groot, dat een breed draagvlak in de politiek en samenleving nodig is om tijdig uitvoerbare oplossingen te ontwikkelen en te implementeren. De bovengenoemde dilemma's lijken dit brede draagvlak onmogelijk te maken.

De filosoof Bruno Latour laat in zijn boeken Oog in oog met Gaia. Acht lezingen over het Nieuwe Klimaatregime (2017) en Waar kunnen we landen? Politieke oriëntatie in het Nieuwe Klimaatregime (2018) zien dat de levensgrote dilemma's en de onoplosbaarheid van de klimaatcrisis te maken heeft met een 'verborgen vooronderstelling' of een 'verborgen dimensie' in ons denken. Hij suggereert dat die verborgen dimensie iets te maken heeft met verbindingen, met betrokkenheid, met heiligheid, met religie.

Op het eerste gezicht lijkt deze bewering vergezocht. Immers, en nu spreekt de wetenschapper in mij, het probleem is helder, de oorzaken zijn bekend, er zijn technische en economische oplossingen, en nu moeten we die oplossingen voortvarend implementeren. Maar de filosoof in mij wordt onrustig. Is er wel sprake van (alleen) een technisch probleem? Moeten we alleen opteren voor technologische en economische oplossingen? Wat is die 'verborgen dimensies' precies? Hoe ligt die relatie met religie? Ten slotte, de politicus in mij - ik zit sinds 11 juni voor de ChristenUnie in de Eerste Kamer - vraagt naar de relatie tussen duurzaamheid aan de ene kant en vrede voor de maatschappij aan de andere kant. Ook resoneren termen als recht en gerechtigheid mee.

Mijn rede heeft de volgende opbouw. Ik begin met de beroemde beruchte als $u$ dat passender vindt - rede van Thierry Baudet op de avond van de Provinciale Staten verkiezingen van dit jaar (par. 2). Daarna geef ik uitgebreid aandacht aan de visie van Bruno Latour op het zogenaamde Nieuwe Klimaatregime (par. 3). Achtereenvolgens bespreek ik vier aspecten van de visie van Latour: de idee van verbroken verbindingen (par. 4), de vraag naar het heilige (par. 5), de dans van de moderne mens 
(par. 6) en de (politieke) elites en de overheid (par. 7). Ik doe dit mede aan de hand van het werk van de filosofen Ferry, Szerszynski en Dooyeweerd. Ik sluit af met mijn eigen positie in dit debat (par. 8) en een dankwoord (par. 9). In een Excurs bespreek ik de wetenschappelijke bewijzen voor klimaatverandering en het fenomeen van klimaatontkenning (par. 10).

\section{Utopie, klimaatontkenning en religie}

Ik begin met de actualiteit. Op 20 maart 2019 werden er in Nederland verkiezingen gehouden voor de Provinciale Staten. Alle aandacht ging uit naar een nieuwe partij: Forum voor Democratie. Deze partij haalde bij de eerdere verkiezingen voor de Tweede Kamer 2 van de 150 zetels. De spannende vraag was: hoeveel zetels gaat deze partij in de Provinciale Staten halen? En wat betekent dat voor de samenstelling van de Senaat? Forum voor Democratie haalde maar liefst 86 van de 570 statenzetels binnen. Uiteindelijk werden ze ook de grootste fractie in de Eerste Kamer: 12 zetels. $^{2}$

Op de verkiezingsavond gaf Thierry Baudet, de partijleider van Forum voor Democratie, een speech waarin hij een schets gaf van de toekomst van de Nederlandse samenleving. Ik geef bewust wat langere citaten om het geheel van zijn visie recht te doen. Baudet begint met een schets van de situatie:

'En zo staan we hier vanavond. Te elfder ure, letterlijk. Te midden van de brokstukken van wat ooit de grootste en mooiste beschaving was die de wereld ooit heeft gekend. Een beschaving die alle uithoeken van de wereld bestreek, die vol zelfvertrouwen was, en die de mooiste architectuur, de mooiste muziek en de mooiste schilderkunst heeft voortgebracht die ooit onder de sterrenhemel heeft bestaan. Ons land maakt onderdeel uit van die beschavingsfamilie. Maar net als al die andere landen van onze boreale wereld, worden we kapotgemaakt door de mensen die ons juist zouden moeten beschermen. We worden ondermijnd door onze universiteiten, onze journalisten. Door de mensen die onze kunstsubsidies ontvangen en die onze gebouwen ontwerpen. En vooral worden we ondermijnd door onze bestuurders. Een kliekje omhooggevallen netwerkers, beroepsvergaderaars, mensen

2 Enkele maanden later splitsten drie Eerste Kamerleden zich af en gingen als de groep Otten verder. 
die nog nooit een boek hebben gelezen in hun leven en geen idee hebben wat op de lange termijn de issues zijn. Zij beheersen helaas de besluitvormingsorganen van ons land, en maken in een merkwaardige mengeling van onkunde en cynisch eigenbelang keer op keer de verkeerde keuzes. Niet lang meer!'

Baudet is van mening dat de afbraak van onze cultuur een broedplaats is voor een nieuwe 'duurzaamheidsreligie'. Hij schrijft:

In al dat ongeloof, in dat immense vacuüm, dat culturele en spirituele vacuüm is tegelijkertijd haast ongemerkt een grandioze ketterij binnengedrongen. Een nieuwe immanente religie, een politieke theologie. De leden van het kartel, ze geloven in niets maar vereren tegelijkertijd een afgod, genaamd transitie. Honderden miljarden (...) willen zij offeren op het altaar van deze afgod. In de vorm van windmolens, warmtepompen, zonnepanelen en andere volkomen onrendabele projecten die ons niets brengen, die de planeet niets verder helpen, maar die ons wel heel erg veel geld kosten en dus heel erg straffen. Het is een masochistische ketterij, dit geseculariseerde zondvloedgeloof dat zich in onze tijd heeft meester gemaakt van de harten en geesten van onze bestuurders (...) Deze duurzaamheidsafgoderij stort niet alleen onze economie in onze totale ondergang, Hij is ook bedoeld om onze geest, ons zelfbewustzijn nog verder te krenken. Inderdaad, schuldgevoel is hetgeen waar deze klimaathekserij zich mee voedt. Wij moeten boeten, zo papegaaien de macht zoekende bestuurder van dit land de ecologische hogepriesters na.'

Baudet sluit af met een uitdagend toekomstperspectief. Hij gelooft dat de uil van Minerva - een klassiek symbool van wijsheid - is opgestegen en de hele aarde in beweging heeft gebracht. Hij gelooft dat onder leiderschap van Forum voor Democratie Nederland kan opstaan uit de ruïnes van het verleden:

'Want op deze dag, nu we in deze crisis verkeren, deze schemer, deze zonsondergang, op deze dag is de uil van Minerva dan toch opgestegen. Vandaag is Forum voor Democratie de grootste, ofwel de gedeelde grootste, ofwel de een na grootste partij van Nederland geworden!

De kiezers in Nederland hebben net als de uil van Minerva hun vleugels uitgespreid. Hebben hun ware macht getoond. De uil der wijzen is gaan vliegen en heeft de hele aardkring in beweging gebracht. Want 
deze vleugels zijn niet alleen vleugels om mee te vliegen. Het zijn ook wieken om lucht mee te slaan. Om een veranderingswind in gang te zetten. Om ons land weer van ons te maken en een einde te maken aan een tijdperk van culturele, economische en politieke capitulatie (...) En vandaag (...) hebben we gekozen om weer te strijden. Weer te dromen, weer te hopen, weer te vechten (...) Als FvD'ers weten wij dat je de metafysische grondslagen van het christendom niet hoeft te aanvaarden om toch de wederopstandingsgedachte als leidend motief van de westerse beschaving te kunnen aanvaarden. lets dat dood leek, iets dat voorbij leek, iets dat achter ons zou liggen, iets dat definitief achter ons zou liggen, dat kan, zo weten wij, weer tot bloei komen. Het idee dat iets dat dood was, iets dat voorbij was weer tot bloei kan komen, precies dat, precies dat beste vrienden, is onze leidraad. Is ons motief, ons levensmotto. Want wij zijn de partij van de wedergeboorte, van de renaissance. Dat is wat wij willen bewerkstelligen (...) Want vrienden, wij gaan met deze partij de trots van ons land herstellen. Op deze rots gaan wij onze zuil bouwen. We gaan onze democratie herstellen, en vandaag is de eerste grote veldslag gewonnen.'

In deze speech vallen een aantal dingen op. Als eerste, Baudet gebruikt veel woorden en motieven die aan het christendom zijn ontleend. Zo spreekt hij van ongeloof, ketterij, offer, altaar, afgod, zondvloed en wederopstanding. Ook gebruikt hij christelijke motieven als zondeval, verlossing en vernieuwing. Het motief van de zondeval vinden we terug in al die wetenschappers, kunstenaars en bestuurders die onze cultuur in het verderf hebben gestort. Het motief van de verlossing komt sterk naar voren in de idee van de wederopstanding van onze beschaving. En het motief van de vernieuwing blijkt uit de rol van de partij: onder leiding van Forum voor Democratie zal onze cultuur weer tot bloei komen.

Als tweede, de religieuze woorden en motieven krijgen hun betekenis binnen een bepaald frame; een frame waarin de wereld verdeeld wordt in twee partijen. Aan de ene kant vind je de wetenschappers, kunstenaars en bestuurder. Zij zijn de zondaars, warhoofden, valse profeten, ecologische priesters, en afgodendienaars. Aan de andere kant vind je de leden van Forum voor Democratie die als ware profeten het volk verlossen en in het beloofde land brengen. Over deze framing valt veel te zeggen. Ik beperk me tot de opmerking dat dit frame een openbaringskarakter heeft: de uil van Minerva is neergedaald. 
Als derde, in de visie van Baudet over de toekomst vinden we twee utopische beelden terug. Het eerste beeld is dat van de sprong voorwaarts. We moeten ons lot in eigen handen nemen, we moeten stoppen met de ketterij van de duurzaamheid, de immigratie een halt toeroepen en de Europese Unie verslaan. Dan zal onze cultuur weer gaan bloeien en zullen rijkdom en welvaart weer ons deel worden. Het tweede beeld is dat van de sprong achterwaarts. Een sprong naar de tijd dat er in ons land alleen maar mensen met een witte huidskleur woonden ('boreale wereld'), de Islam in nog geen velden of wegen te bekennen was, en vrouwen nog onderschikt aan mannen waren. Ook over deze toekomstbeelden valt veel te zeggen. Ik onthoud me - en dat valt me moeilijk - van een filosofische, morele en rechtstatelijke analyse van deze beelden. Ik beperk me tot de opmerking dat Baudet geen wetenschappelijke en politieke onderbouwing geeft van de door hem gepresenteerde beelden. Daarnaast lijkt het een lastige opgave om beide beelden tegelijkertijd te realiseren: om zowel een sprong voorwaarts als een sprong achterwaarts te maken. Het zou wel eens kunnen zijn dat Baudet een utopie nastreeft in de letterlijke betekenis van het woord, namelijk een niet-bestaande plaats.

In zijn speech gebruikt Baudet het woord 'religie' of 'religieus' voor een bepaalde politieke opvatting. Namelijk, de opvatting dat er sprake is van een serieuze dreiging op het gebied van het klimaat. Ik laat in het midden of deze karakterisering juist is. Ook laat ik in het midden of Baudet niet valt in de valkuil die hij zelf gegraven heeft: moet zijn eigen visie ook niet als religieus bestempeld worden? Ik wil namelijk graag een spade dieper graven. Het mij om de vraag of er in de wetenschap zelf niet al sprake is van religie of religieuze keuzen. Los van de vraag of je voor of tegen een bepaald politiek standpunt met betrekking tot het klimaat bent.

\section{Bruno Latour: de verborgen dimensie}

Bruno Latour vertelt in zijn boek Oog in oog met Gaia. Acht lezingen over het Nieuw Klimaatregime dat hij een keer een dansbeweging zag waar hij zich niet meer van kon losmaken. Hij zegt daarover het volgende: 'Een danseres, die achterwaarts vlucht voor iets wat haar blijkbaar afschuw inboezemt, kijkt al rennend voortdurend achterom, steeds angstiger, alsof er achter haar - juist doordat ze vlucht - voortdurend obstakels bijkomen, die haar steeds meer belemmeren in haar bewegingen, tot 
ze zich wel helemaal moet omdraaien, en stokkend, perplex, met slappe armen ziet hoe er iets op haar afkomt dat nog angstaanjagender is dan datgene waarvoor ze eerst is gevlucht - zo erg dat ze terugdeinst. Door te vluchten voor iets gruwelijks, stuit ze op een andere gruwel die deels door haar vlucht is veroorzaakt' (Latour, 2017, p. 13).

Latour associeerde deze dans in eerste instantie met de tijdgeest. De danseres verbeeldt de moderne mensheid die vlucht voor het verleden en op die vlucht komt ze monster tegen dat ze mede door haar vlucht heeft veroorzaakt. En dat monster is zo afschuwelijk dat ze terugdeinst. Later, door het lezen van het werk van James Lovelock, vereenzelvigde hij dit monster met Gaia, de Aarde. Dit beeld liet Latour niet meer los. Hij schrijft: 'Ik kon er niet meer onderuit: ik moest inzicht krijgen in wat zich aan mij opdrong in de tamelijk beangstigende vorm van een kracht die tegelijk mythisch, wetenschappelijk, politiek en waarschijnlijk ook religieus was' (Latour, 2017, p. 13). Later heeft Stéphanie Ganachaud op verzoek van Latour deze dans op een indrukwekkende wijze uitgevoerd. ${ }^{3}$

\section{Wat is er gebeurd?}

Latour heeft het gevoel dat deze beangstigende dans een treffende verbeelding is van de geschiedenis van onze moderne westerse samenleving. In de weg van wetenschap en techniek hebben we ons ontworsteld aan ons onzekere bestaan en zijn we niet meer overgeleverd aan de krachten van de natuur. We beheersen de natuur, hebben de voedselproductie in eigen hand, beschermen ons tegen natuurgeweld en strijden succesvol tegen ziekten en epidemieën. Maar deze beheersing lijkt een prijs de hebben: de Aarde komt in opstand. De Aarde is verworden tot een angstaanjagend monster dat zich tegen ons keert. Daarmee zitten we in het hart van de problematiek: kritiek op de moderne samenleving, op de ontwikkeling van wetenschap en techniek, op de elites en de politiek. Ik werk dit verder uit.

In zijn boek Waar kunnen we landen? Politieke oriëntatie in het Nieuwe Klimaatregime gebruikt Lateur het beeld van een toneelspel in de schouwburg. Centraal staat het spel van de acteurs. Zij spelen een actieve rol en bepalen de ontknoping. De decors, de coulissen, het achtertoneel en het gebouw hebben een passieve rol: ze vormen de context van de acteurs. Dit beeld geeft een goede beschrijving van de

3 www.vimeo.com/60o64456. 
verhouding tussen de moderne mens en de aarde. In het hele proces van de modernisering van de samenleving speelden de mensen de hoofdrol en fungeerde de aarde als een passieve en onproblematische context. Maar in de laatste decennia is daar verandering in gekomen: de passieve en onproblematische context neemt ook een hoofdrol op zich. Latour (2018, p. 56) schrijft: 'Vandaag zijn het decor, de coulissen, het achtertoneel, het hele gebouw het toneel opgeklommen en betwisten ze de acteurs de hoofdrol. Dat verandert alle scripts, suggereert andere ontknopingen. Mensen zijn niet langer de enige acteurs, al krijgen ze nog steeds een rol toebedeeld die veel te belangrijk voor hen is.'

Latour spreekt daarom over een 'Nieuw Klimaatregime' - een term die we in de ondertitel van beide boeken tegenkomen. Er is een verandering opgetreden in de fysieke omgeving van de mens. De moderne mens heeft tot voor kort de fysieke omgeving als een vaststaand gegeven beschouwd, als de vaste grond waarop het project van de moderniteit zich ongehinderd kon ontwikkelen (Latour, 2017, p. 16). Kort samengevat, de mens als subject en de aarde als object. Maar dat passieve object blijkt handelingsvermogen te hebben: de Aarde slaat terug en bedreigt de mens. De Aarde is een 'nieuwe politieke actor' geworden (Latour, 2018, p. 53). Met die actor moeten we rekening houden, of we het willen of niet. Hij waarschuwt er voor om 'de verdeling van de handelingsvermogens tussen menselijke en niet-menselijke actoren niet op voorhand [te] simplificeren' (Latour, 2017, p. 97).

\section{Bredere samenhang}

Het is verleidelijk om de klimaatcrisis als een separaat probleem te zien. Een probleem, en nu spreekt de wetenschapper in mij, dat we goed moeten definiëren en waarvoor we technologische oplossingen moeten ontwikkelen en implementeren. Ik denk dat Latour deze formulering zou willen aanscherpen. Hij zou zeggen: 'gebruik niet de woorden "de wetenschapper in mij" maar spreek over "de moderne wetenschapper in mij".' Die correctie is erg belangrijk. Ik kom daar op terug. Latour stelt nadrukkelijk dat de klimaatcrisis slechts één van de gebieden is waar het falen van de moderne mens naar voren komt.

Latour (2018, p. 11-12) signaleert verschillende verschijnselen die in zijn visie nauw samenhangen:

- deregulering;

- explosie van ongelijkheden; 
- migratiecrisis;

- ontkenning van de klimaatverandering;

- panisch verlangen naar bescherming door de natiestaat / opkomst van het populisme.

Latour stelt dat er sinds de jaren tachtig van de vorige eeuw een wind van deregulering door de westerse wereld waait. De leidende gedachte is dat de markt meer speelruimte moet hebben om welvaart en voorspoed te brengen. Tegelijkertijd constateert hij dat de ongelijkheden in de wereld sterk toenemen: de rijken worden steeds rijker en de kloof met de armen wordt steeds groter. Door een combinatie van oorlogen, falende economische ontwikkeling en klimaatverandering worden miljoenen mensen van hun geboortegrond verjaagd en gaan op zoek naar een ander grondgebied. Een ander fenomeen is dat van de klimaatontkenners. Er zijn politici en bedrijven die ontkennen dat er sprake is van een klimaatcrisis. Ten slotte, het panische verlangen naar bescherming door de eigen staat. Een verlangen dat zich uit in de opkomst van populistische partijen. In de visie van Latour hangen al deze fenomenen nauw samen. Populair uitgedrukt, de opkomst van de Zuidas, de ontkenning van de klimaatcrisis, de protesten van de gele hesjes, de vluchtelingenstroom uit Syrië, de opkomst van het populisme en de liberalisering van de samenleving, zijn allemaal symptomen van een en dezelfde historische situatie: het falen van het project van de moderniteit.

\section{Falen van de moderniteit}

Latour beschrijft het falen van de moderniteit in scherpe bewoordingen. Hij spreekt over de 'ravages van de globalisering' en de 'afgronden die door de modernisering zijn geslagen' (Latour, 2018, pp. 22, 120). Latour haalt hard uit naar de (politieke) elites. 'Het is', zo schrijft hij, 'alsof een groot deel van de leidende klassen (...) tot de conclusie is gekomen dat er op aarde niet genoeg plaats meer is voor henzelf én voor andere mensen' (Latour, 2018, p. 11). Hij signaleert het ontbreken van een 'gemeenschappelijke horizon' waarin 'alle mensen' in gelijke mate kunnen floreren (Latour, 2018, p. 12). Hij stelt dat Amerika met het terugtrekken uit het Parijse klimaatakkoord op een pijnlijke wijze helderheid heeft geschapen: 'ledereen weet nu dat de klimaatkwestie tot de kern van de geopolitieke issues behoort en dat ze rechtstreeks verbonden is met vraagstukken van onrechtvaardigheid en ongelijkheid' (curs. BL) (Latour, 2018, p. 13). De boodschap van die terugtrekking is: 'Wij Amerikanen behoren niet tot dezelfde aarde als jullie. Die van jullie mag 
bedreigd zijn, die van ons zal dat niet gebeuren' (Latour, 2018, p. 13). Hij is van mening dat de Amerikaanse elites 'donders goed hebben begrepen dat de waarschuwing (over de klimaatcrisis, MJV) gegrond was', maar dat ze niet de conclusie wilden trekken dat zij voor het omkeringsproces van de Aarde duur moesten betalen (Latour, 2018, p. 28). ${ }^{4}$ Hij schrijft dat ze 'verlicht genoeg [waren] om het alarmsignaal op te vangen, maar niet verlicht genoeg om het resultaat ervan publiekelijk te delen' (Latour, 2018, p. 29). Integendeel, ze trokken twee politieke conclusies die later door president Trump - de Tweeter-in-Chief - met verve werden uitgedragen: 'Ten eerste: ja, die ommekeer zal duur moeten worden betaald, maar wij gaan daar niet voor opdraaien, dat mogen de anderen doen. En ten tweede: die steeds minder betwistbare waarheid van het Nieuwe Klimaatregime, daarvan gaan we gewoon glashard het bestaan ontkennen' (curs. BL) (Latour, 2018, p. 29). Latour haalt de 'sleetse metafoor' van de Titanic van stal: 'de leidende klassen begrijpen dat de schipbreuk onvermijdelijk is, ze maken zich meester van de reddingsboten, en ze vragen het orkest lang genoeg slaapliedjes te blijven spelen zodat ze er in het nachtelijk duister vandoor kunnen gaan voordat de andere klassen door een overmatige slagzij worden opgeschrikt' (Latour, 2018, p. 30).

\section{Fundamentele oorzaak van de problemen}

Waarom is het allemaal zo uit de hand gelopen? Latour wijt het falen van het project van de moderniteit aan de natuurwetenschappelijke opvatting van rationaliteit die dit project in zijn greep heeft gekregen. Hij richt zijn pijlen van kritiek op vier bijvoeglijke naamwoorden die karakteristiek waren voor deze rationaliteit: realistisch, objectief, efficiënt en rationeel. Hij schrijft: 'Hoe kunnen we een moderniseringsproject dat sinds twee eeuwen "vergat" te anticiperen op de reacties van de aardbol op het menselijke handelen nog als "realistisch" beschouwen? Hoe kunnen we de "objectiviteit" van de economische theorieën aanvaarden die niet in staat zijn te verdisconteren dat de hulpbronnen waarvan ze de uitputting juist hadden moeten voorzien schaars blijken te zijn? Hoe kunnen we spreken over "efficiency" bij technische systemen die in hun ontwerp niet weten te integreren hoe ze langer in gebruik blijven dan een paar decennia? Hoe kunnen we een beschavingsideaal "rationalistisch" noemen dat zich schuldig heeft gemaakt aan een zo kolossale inschattingsfout dat ze ouders de mogelijkheid ontzegt hun kinderen een bewoonbare planeet achter te laten?' (Latour, 2018, pp. 79-80).

4 Zie ook Latour (2017, p45-46). 
Latour verwijt de moderne wetenschap dat het kennen 'van buitenaf' de norm is geworden. Het moderne en progressieve wordt geïdentificeerd als 'extern', 'objectief' en 'kenbaar' en het verleden en de traditie als 'onwerkelijk', 'subjectief' en 'onkenbaar' (Latour, 2018, p. 82, 85). Die objectiviteit heeft als keerzijde onthechting en niet-betrokkenheid. In de woorden van Latour: alsof de theorieën en visies van de moderne wetenschap 'buiten de sociale wereld staat en volkomen onverschillig zijn voor de bekommernis van mensen' (curs. BL) (Latour, 2018, p. 80). De dingen van buitenaf bekijken is het 'enige middel' geworden om zich te 'oriënteren op de toekomst' (curs. BL) (Latour, 2018, p. 85). Latour (2018, p. 87 ) stelt dat het Aardse zo'n 'onthechtheid' niet toestaat.

Latour bekritiseert de technische en filosofische modellen die voor de Aarde gebruikt worden. Hij meent dat subject (mens) en object (Aarde) niet meer 'dialectisch tegenover elkaar kunnen worden geplaatst' (Latour, 2017, p. 96). Ook vindt hij dat het onderscheid tussen delen en geheel - een ingenieursbenadering - niet van toepassing is op de interacties tussen objecten en organismen (delen) en de Aarde (geheel) (Latour, 2017, p. 142). Latour wil de natuurwetenschappelijke blik op de Aarde vervangen door een beeld dat recht doet aan de Aarde als actor. In zijn visie voldoet het beeld van Gaia aan deze eis. Hij schrijft: 'Gaia, Gè, Aarde, is namelijk geen godin in de eigenlijke zin des woords, maar een kracht uit de tijd van vóór de goden' (curs. MJV) (Latour, 2017, p. 121). Het gaat Latour dus niet om de mythische of religieuze betekenis van Gaia maar om de idee van een 'kracht'. In de visie van Latour is Gaia een beeld dat ruimte creëert voor 'verbindingseffecten tussen handelingsvermogens' zonder terug te vallen op een 'onhoudbare opvatting van totaliteit' (curs. BL) (Latour, 2017, pp. 143-144). Daarom kan hij ook schrijven dat het klimaat een 'historische resultante van wederzijdse verbindingen' is (Latour, 2017, pp. 155-156).

Latour wil dus onze visie op de Aarde bevrijden van technische en religieuze modellen om zicht te krijgen op de Aarde als actor. Hij schrijft: 'Juist in dit opzicht is Gaia geen organisme, en kunnen we er geen technisch of religieus model op toepassen. Ze heeft misschien een orde, maar geen hiërarchie; ze is niet geordend in opeenvolgende niveaus; ze is ook niet wanordelijk (...) dat is wat Lovelocks Gaia volslagen profaan maakt (...). Bij ontstentenis van kader, doel of richting, moeten we Gaia beschouwen als de naam van een proces waardoor variabele, contingente voorvallen latere gebeurtenissen waarschijnlijker hebben gemaakt' (curs. MJV) (Latour, 2017, pp. 156-157). 


\section{Alarmbellen en sirenes}

Latour schenkt veel aandacht aan de vraag hoe het toch komt dat we zo rustig en onbewogen blijven onder de dreiging van de klimaatcrisis, dat we uitstralen dat ons niets kan overkomen, dat het er op lijkt dat we zelfs ongeïnteresseerd en onverschillig zijn. 'Het komt niet', zo stelt hij, 'doordat er geen alarm is geslagen; het komt niet doordat de alarmbel overal nijdig was uitgeschakeld; nee, de sirenes loeiden oorverdovend en toch wordt manhaftig besloten zich door de gevaren niet te laten afremmen' (Latour, 2017, p. 272). In de visie van Latour is er sprake van een bewuste keuze om het gevaar niet af te wenden. Deze bewuste keuze heeft in zijn visie een religieuze oorsprong (Latour, 2017, p. 273).

Latour stelt dat de Moderniteit de alarmbellen niet gehoord heeft omdat ze in de greep is van de moderne utopie of heilsleer. Hij typeert deze houding als religieus (Latour, 2017, p. 273 e.v.). Hij is van mening dat moderne mensen geloven dat de toekomst in de weg van wetenschap en beheersing gerealiseerd kan worden. Beter: eigenlijk al gerealiseerd is. Latour (2017, p. 274) schrijft:'De Moderniteit leeft volledig in de Apocalyps of, om het preciezer te zeggen, na de Apocalyps' (curs. BL). Moderne mensen geloven dat ze al 'aan de overzijde zijn', dat ze 'niet meer van deze wereld zijn' en dat ze 'volkomen en voor altijd modern zijn geworden' (curs. BL) (Latour, 2017, p. 277). Juist omdat ze geloven dat ze het 'Beloofde Land van de Moderniteit' bereikt hebben, kunnen ze niet geloven dat ze die belofte verkeerd begrepen hebben en dat de Aarde zich tegen hen keert (Latour, 2017, p. 292). 'Ze hebben onachtzaamheid tot hun hoogste waarde verheven' (curs. BL) (Latour, 2017, p. 277).

Latour analyseert ook waarom christenen de sirenes niet gehoord hebben. Hij meent dat de argumentatie die Lynn White in zijn bekende artikel 'The Historical Roots of Our Ecological Crisis' toepast - namelijk dat God de mens de absolute macht over de natuur had gegeven onjuist is. In Latours visie heeft de christelijke religie ergens tussen de dertiende en de achttiende eeuw haar aanvankelijke roeping verloren onder invloed van de gnostiek en de wetenschap. Geleidelijk aan lieten christenen 'elke bekommernis om de kosmos varen en wijdden ze zich nog uitsluitend aan het heil der mensen, en bij de mensen vervolgens alleen nog aan het zielenheil' (Latour, 2017, p. 296). Hij schrijft: 'Terwijl ze (christenen, MJV) zich meenden toe te leggen op de Geest, verloren ze de Aarde (Latour, 2017, p. 297). 


\section{Waar kunnen we landen?}

Latour (2018, p. 16) schetst twee opties: 'Blijven we dromen van ontsnapping of komen we in beweging om een territorium te vinden dat wij en onze kinderen kunnen bewonen? Ofwel we ontkennen het bestaan van het probleem, ofwel we zoeken een plaats om te landen.' Latour is van mening dat dromen van ontsnapping of het ontkennen van het probleem geen optie is. Hij schrijft: 'Het is onze enige uitweg: gezamenlijk ontdekken welk territorium bewoonbaar is en met wie we het moeten delen' (Latour, 2018, p. 20).

Latour stelt dat we alleen voortgang kunnen boeken als we een nieuw contrast kunnen invoeren tussen 'enerzijds de termen religieus of seculier en anderzijds de term aards' (curs. BL) (Latour, 2017, p. 298). Hij vervolgt: 'Het aardse is noch het profane, noch het archaïsche, noch het heidense, noch het materiele, noch het seculiere, het is alleen wat voor ons ligt, als een daadwerkelijk nieuwe Aarde' (Latour, 2017, p. 298). Latour roept zijn lezers op om oog in oog met Gaia te staan: 'Gaia als signaal dat we op Aarde moeten terugkeren. Om de werking van Gaia samen te vatten, zouden we kunnen zeggen dat Gaia het enige middel is om de Modernen weer te laten beven van onzekerheid over wat ze zijn (...) en om van hen te eisen dat ze eindelijk het heden serieus nemen' (curs. BL) (Latour, 2017, p. 308).

\section{Verborgen dimensie}

Als we de voorgaande paragrafen tot ons door laten dringen, dan worden de contouren van de verborgen dimensie van de klimaatcrisis steeds duidelijker. Niet alleen die van de klimaatcrisis, maar ook van de andere verschijnselen die eerder genoemd zijn: explosie van ongelijkheden, migratiestromen en de opkomst van het populisme. De eerste contour vinden we in de duiding van de relatie van de mens met de medemens en de relatie van de mens met de natuur. Het gaat om woorden als 'kennen van buitenaf', 'onverschilligheid' en 'onthechtheid'. Ik wil deze woorden samenvatten in de notie 'verbroken verbindingen'. 5 De tweede contour vinden we in de existentiële duiding van de mens zelf. Het gaat om begrippen als religie en seculariteit, het sacrale en het profane, Gaia en de Aarde.

5 Latour gebruikt de notie 'verbroken verbinding' zelf niet. Het woord 'verbinding' gebruikt hij positief als hij spreekt over Gaia. Hij gebruikt dan woorden als 'verbindingseffecten' en 'wederzijdse verbindingen' (Latour, 2017, pp. 143, 156). Het woord 'verbroken' karakteriseert de negatieve houding van 'buitenaf', 'onverschillig' en 'onthechtheid'. Ook past dit woord goed bij de negatie van de moderne mens van de Aarde als actor. 


\section{Intellectuele moed}

Ik ben diep onder de indruk van de betrokkenheid van Bruno Latour bij de klimaatcrisis. Ik ben ook diep onder de indruk van zijn eruditie en denkvermogen. Maar het meest ben ik nog onder de indruk van zijn intellectuele moed om als wetenschapper te laten zien dat feiten 'vragen' om een morele en politieke duiding. Zeker in een cultuur waarin 'merchants of doubt' proberen om intellectuelen die een ongemakkelijke boodschap brengen, het zwijgen op te leggen of hun integriteit in twijfel te trekken (Oreskes \& Conway, 2010).

\section{Latour en Baudet}

Ik kom nog even terug op de overwinningsspeech van Baudet. Hoe zou Latour die beoordelen? Ik denk dat Latour Baudet zal scharen bij de politici die geloven dat de Moderniteit hen in het Beloofde Land zal brengen. Daarnaast zal Latour de visie van Baudet karakteriseren als 'postpolitiek'. Dat wil zeggen, als 'een politiek zonder object' omdat hij wereld verwerpt waarin hij beweert te wonen (Latour, 2018, p50). Ten slotte, Latour zou Baudet scharen onder politici als Trump, die heel goed begrepen hebben dat de waarschuwingen over de klimaatcrisis gegrond zijn, maar die daar geen politieke conclusies uit willen of durven trekken (Latour, 2018, pp. 28-29).

\section{Uitwerking}

In het vervolg van mijn rede wil ik vier thema's in het denken van Latour verder uitwerken:

1. De notie van 'verbroken verbindingen'

2. De vraag naar het heilige

3. De dans van de moderne mens

4. De (politieke) elites en de overheid

Bij de uitwerking gaat het mij niet alleen om de filosofische analyse, maar ook om de morele en de politieke betekenis daarvan. De reden is dat als de sirenes oorverdovend loeien - om in een beeld van Latour te blijven - wetenschappers zich niet kunnen terugtrekken in hun laboratorium als zouden wetenschappelijke feiten en theorieën 'neutraal' zijn en geen morele implicaties hebben (Latour, 2017, p. 41-57. Filosofisch uitgedrukt: natuurwetenschappelijke feiten hebben een moreel aspect. In die zin zijn wetenschappelijke feiten nooit neutraal. 
Laat ik dit met een alledaags voorbeeld duidelijk maken. Als ik een klein kind in de richting van een snelstromende rivier zie lopen dan is dat een feit. In één oogopslag maak ik een inschatting van de situatie: de snelheid van het kind en de afstand tot de rivier. Daarnaast ken ik de context: de hoogte van de kade, de stroomsnelheid van de rivier, enzovoorts. Voor iedereen is duidelijk dat de constatering 'een kind loopt hard naar een snelstromende rivier' inderdaad een feit is. Maar ook is voor iedereen duidelijk dat van dit feit een moreel appel uitgaat: ik word opgeroepen om de fatale loop van het kind te onderbreken.

\section{De notie van 'verbroken verbindingen'}

De Franse filosoof Luc Ferry heeft een boek geschreven over de geschiedenis van de filosofie. ${ }^{6}$ In het Nederlands heeft dit boek de titel meegekregen Beginnen met filosofie. Met andere ogen kijken naar jeleven (2006). In de Engelse taal kwam het op de markt als Learning to Live: A User's Manual (2010). Deze laatste titel geeft een mooie karakterisering van de visie van Luc Ferry op de filosofie. In zijn visie hebben we de filosofie nodig om iets te 'begrijpen van de wereld waarin we leven' en om ons te helpen een 'beter en vrijer leven te leiden' (Ferry, 2006, p. 11-12). Zijn boek is dan ook een reisgids, een gebruikershandleiding.

Ferry bespreekt de hoogtepunten uit de geschiedenis van de filosofie. Hij gaat uitgebreid in op het Griekse denken, de opkomst van het christendom, het ontstaan van de moderne filosofie en het postmoderne denken. Elk hoogtepunt probeert hij te begrijpen door drie onderwerpen voor het voetlicht te halen (Ferry, 2006, p. 26):

1. het begrijpen van de werkelijkheid (theorie);

2. het verlangen naar rechtvaardigheid (ethiek); en

3. het zoeken naar heil (wijsheid).

Ferry laat zien dat de loop van de geschiedenis de visie op de werkelijkheid, rechtvaardigheid en heil sterk veranderd is. In zijn visie is er sprake van breuken: een breuk tussen het Griekse denken en het christendom, het christendom en de moderne filosofie, de moderne filosofie en het postmoderne denken. Hij is van mening dat een nieuwe breuk nodig

6 Dit boek heb ik uitgebreider besproken in mijn oratie (Verkerk, 2010). 
is omdat het postmoderne denken onvoldoende handvatten biedt om een beter en vrijer leven te leiden. De manier waarop Ferry naar de geschiedenis van de filosofie kijkt helpt ons om meer inzicht te krijgen in de vraag naar de notie van verbroken verbindingen.

Ferry laat zien dat in de Griekse filosofie, hij beperkt zich tot het denken van de stoïcijnen, de werkelijkheid wordt gezien als één groot organisme dat op volmaakt wijze is samengesteld. Elk orgaan vervuld zijn eigen functie, bevindt zich op de juiste plaats en werkt met de andere organen op een harmonieuze manier samen. Deze geordende structuur noemen de Grieken het 'goddelijke' of de 'logos'. De opkomst van het christendom impliceert een radicale breuk met het Griekse denken. Het goddelijke, de logos, wordt niet langer gelijkgesteld met de kosmos maar neemt de gedaante aan van een persoon: Jezus Christus. De apostel Johannes (Johannes 1) beschrijft deze breuk als volgt:

' 1 In het begin was het Woord [logos], het Woord [logos] was bij God en het Woord [logos] was God. 2 Het was in het begin bij God. 3 Alles is er door ontstaan en zonder dit is niets ontstaan van wat bestaat ... 14 Het Woord [logos] is mens geworden en heeft bij ons gewoond, vol van goedheid en waarheid, en wij hebben zijn grootheid gezien, de grootheid van de enige Zoon van de Vader.'

De stoïcijnen zouden het met de eerste drie verzen waarschijnlijk wel eens zijn. Maar bij het veertiende vers gaat het mis. De gedachte dat het goddelijke mens is geworden - en dat de discipelen de getuigen waren van deze menswording - is voor hen de 'waanzin ten top' (Ferry, 2006, p. 68). Dit citaat laat zien dat in het christelijke denken alle verbindingen samenkomen in Jezus Christus: de verbinding met God ('bij God'), de verbinding met de werkelijkheid ('alles is er door ontstaan') en de verbinding met de mens ('heeft bij ons gewoond'). De verbinding tussen mensen komt scherp naar voren in de christelijke ethiek die gebaseerd is op de 'wet van de liefde': de naaste liefhebben als jezelf. Ferry (2006, p. 82) stelt dat door de christelijke ethiek het begrip 'mensheid' een nieuwe betekenis krijgt. Namelijk, de gelijkwaardigheid van alle mensen.

De beschrijving van Ferry maakt mijns inziens twee dingen duidelijk. Als eerste dat in het christelijke denken alle verbindingen hun oorsprong in Jezus Christus vinden. Daarmee is de vraag naar 'verbindingen' ook een 
religieuze vraag. Als tweede dat verbindingen in het christelijke denken niet gefundeerd zijn in de mens zelf maar in iemand buiten de mens: Jezus Christus, de Zoon van God.

De ontwikkeling van de moderne filosofie - het tijdperk van het humanisme - gaat uiteindelijk gepaard met een afwijzing van de fundering in Jezus Christus. De moderne mens probeert op eigen kracht de kernvragen van de filosofie over theorie, ethiek en heil te doordenken. Daarmee neemt de mens de gigantische taak op zich om zelf orde te scheppen in een onttoverde kosmos. Ferry (2006, p. 108) is van mening dat we hier te maken hebben met een radicale breuk met het christendom: de mens - beter: de mensheid - wordt het middelpunt van de wereld. Hij of zij neemt de plaats in van de godheid. Tevens wordt de mens ook de grondslag voor de ethiek en is hij verantwoordelijk voor de realisatie van het heil. Vanuit het perspectief van verbindingen verandert er veel. De verbinding met een transcendente God, die zich in Jezus Christus heeft geopenbaard, verdwijnt. De verbinding met de medemens blijft in een geseculariseerde vorm bestaan: onbaatzuchtigheid en gemeenschappelijk belang blijven centraal staan (Ferry, 2006, p. 125). De verbinding met de werkelijkheid verandert sterk: de werkelijkheid is object geworden in het realiseren van het heil op aarde (Ferry, 2006, p. 143). Deze herdefiniëring van de relaties van de mens kan mijns inziens niet anders dan religieus geduid worden.

Ik kom nu tot de visie van Luc Ferry op de postmoderniteit. Hij laat zien dat er een radicale breuk is met het moderne denken. Ferry geeft vooral aandacht aan het 'geval Nietzsche'. In de visie van Nietzsche blijven de nazaten van de moderniteit gevangen in de grondstructuren van de religie omdat ze blijven geloven in waarden die 'hoger dan het leven zijn', zoals de rechten van de mens, wetenschap, rede, sociale rechtvaardigheid, democratie, enzovoorts. Nietzsche presenteert zich als de filosoof 'met de hamer', die de oude idealen - in zijn terminologie 'afgodsbeelden' wil afbreken. Het gaat het om de 'wil tot macht': de individuele mens die zijn leven op scheppende wijze vormgeeft. Nietzsche spreekt dan ook over 'de grote levensstijl'. Alleen door alle verbindingen te verbreken kan de mens waarlijk mens zijn. Alleen zo kunnen we een leven leiden dat waard is om geleefd te worden. Een intens, verheven en moedig leven. Een leven waarin geen ruimte is voor spijt en berouw. De eeuwige wederkeer. 
Eerder heb ik de notie 'verbroken verbindingen' gemunt om, mede op basis van de analyse van Latour, een van de contouren van de verborgen dimensie van de klimaatcrisis te duiden. Ferry laat scherp zien dat 'verbroken verbindingen' het resultaat zijn van een lang historisch proces. Eerst werd de verbinding met God verbroken, daarna de verbinding met de natuur en ten slotte de verbinding met de medemens. Daarmee maakt Ferry duidelijk dat het probleem van verbroken verbindingen een fundamenteel probleem is dat diep verankerd is in de existentie van de (post-) moderne mens. Ik heb aannemelijk gemaakt dat we ook mogen spreken van een religieus fenomeen.

\section{De vraag naar het heilige}

Bronislaw Szerszynski heeft een boek geschreven met de spannende titel Nature, Technology and the Sacred (2005a).7 Dit boek kan ook gezien worden als een reisgids in de filosofie. Bij Ferry ging het om de vragen naar de werkelijkheid, de ethiek en het heil. Bij Szerszinsky gaat het om vragen naar het sacrale en het profane, het heilige en het seculiere.

Szerszynski vraagt zich af hoe we de moderne tijd precies moeten beoordelen. Een wijdverbreide visie is die van Max Weber, de 'onttovering van de wereld': onder invloed van wetenschap en techniek hebben we de natuur gezuiverd van mysterieuze krachten en goddelijke ingrepen. We geloven niet meer in goden, demonen en geesten die ons kunnen helpen, hinderen of bang maken. We geloven tegenwoordig dat de werkelijkheid begrepen kan worden in wiskundige termen en natuurkundige wetten. Sterker nog, we kunnen de natuur beheersen door de wetenschap, haar potenties realiseren door techniek, en haar waarde bepalen in de markt. Samengevat, 'onttovering' wil zeggen dat 'religie is vervangen door wetenschap en techniek' (Szerszynski, 2005a, p. 14).

Szerszynski (2005a, p. 11) laat zien dat het verhaal van de onttovering veel complexer in elkaar zit dan in veel populaire en filosofische beschouwingen wordt beschreven. Hij merkt op dat in de klassieke wereld het begrip 'werelds' of 'profaan' altijd religieus geduid werd. Hij verwijst daarbij naar de originele betekenis van het woord 'profaan': profanum is de ruimte die zich voor het heiligdom bevindt. Ook refereert hij aan Hans-George

7 Dit boek heb ik uitgebreider besproken in mijn oratie (Verkerk, 2010). 
Gadamer die stelt dat het profane altijd het sacrale vooronderstelt. Anders gezegd, in het klassieke denken was het profane altijd een ruimte binnen een sacrale kosmos. Het moderne denken stelt echter dat de wereld volkomen profaan of seculier is en geen enkele spirituele betekenis heeft. In dit denken presenteert het seculiere zich als een 'self-grounding, independent reality' (Szerszynski, 2005b, p. 816). Szerszynski laat zien dat de moderniteit - en daarmee de moderne opvattingen over het sacrale en het seculiere - opgevat moet worden als een specifiek stadium van onze religieuze en culturele geschiedenis. Hij noemt het seculiere zelfs een religieus fenomeen (Szerszynski, 2005b, p. 814).

Szerszynski (2005a, pp. 16-23) beschrijft de ontwikkeling van het sacrale onder het kopje 'The Long Arc of Transcendental Religion'. ${ }^{8}$ Het verhaal begint met het primal sacred van inheemse volken en het eindigt met het postmodern sacred in onze tijd. Ik haal er drie ordeningen uit: het protestantse, moderne en postmoderne.

In het Protestant sacred vindt er een ordening plaats langs de verticale as: er wordt een onderscheid gemaakt tussen de 'wereld hier beneden' en de 'transcendente wereld hier boven'. De kloof tussen het goddelijke en het wereldlijke gezien wordt als oneindig groot én oneindig klein, als absoluut én in het niets verdwijnend. In deze transformatie zien we twee dingen. Enerzijds wordt God getekend als de Verhevene, de Almachtige, de Eeuwige. Anderzijds is Hij nabij en direct toegankelijk voor het individu, zonder hemelse of aardse intermediair. Het protestantse sacrale opent de weg voor het individu - geschapen naar het beeld van God-om op alle gebieden van het profane leven God te dienen. De hele wereld, in al zijn complexiteit en dynamiek, is zijn terrein. Szerszynski gebruikt het woord 'profaan' hier vrijwel in zijn oorspronkelijke betekenis: het 'profane' is direct gerelateerd aan het sacrale en krijgt betekenis vanuit het sacrale.

In het modern sacred, dat onder andere de Verlichting omvat, wordt de verticale transcendente as in toenemende mate in de empirische wereld getrokken. De wereld wordt profaan in een geheel nieuwe betekenis. Namelijk als een ruimte die alleen profaan is en die geen relatie heeft met het sacrale. Het profane is 'totaal' of 'absoluut' geworden (Szerszynski, 2005a, p. 7-9). Het 'ineenstorten' of 'kantelen' van de

8 Szerszynski (2005a, p16) gebruikt het woord 'transcendentaal'. Het woord 'transcendent' zou filosofisch correcter zijn geweest. 
verticale as leidt echter niet tot het verdwijnen van het sacrale maar tot een herordening daarvan: de sacraliteit van het menselijke subject en de sacraliteit van de levensprocessen (Szerszynski, (2005a, pp. 96-102). Met andere woorden, de mens kent zichzelf en de natuur een goddelijk karakter toe. De herordening van het sacrale leidt ook tot een nieuwe visie op verlossing. De verlossing door Christus wordt vervangen door zelfverlossing in de weg van wetenschap en techniek

Als laatste komen we tot het postmodern sacred, waarin het monotheïstisch heilige en het protestants heilige radicaal ineengestort zijn. Er ontstaat een veelvoudige werkelijkheid die gevuld is met en geconstitueerd wordt door verschillende visies op mens en werkelijkheid die gefundeerd zijn in de subjectieve ervaring. Mensen richten zich niet meer naar een natuurlijke of goddelijke orde, maar kiezen voor een eigen levensbeschouwing op basis van 'wat goed voelt' en geven hun eigen religie vorm. De kern van het postmoderne sacrale is dat het 'post-transcendentaal' is: het kan alleen bestaan na het tijdperk van het 'transcendentale monotheïsme'. ${ }^{9}$ De idee van eenheid, die in het moderne sacrale nog aanwezig was, heeft plaatsgemaakt voor pluraliteit.

Szerszynski geeft met zijn 'Long Arc of Transcendental Religion' een bijzonder boeiende schets van de geschiedenis van het sacrale en het profane. De waarde van deze schets is dat hij laat zien dat ons huidige denkklimaat het resultaat is van een langdurig 'historisch proces'. Hij laat zien dat dit langdurige proces niet heeft geleid tot het verdwijnen van het sacrale - wat door veel politici en filosofen wordt gesteld - maar tot een herordening daarvan.

Het is - laat ik daarmee beginnen - niet gemakkelijk om de opvattingen van Latour over het sacrale en het seculiere scherp te krijgen. Hij veronderstelt veel voorkennis bij zijn lezers en gebruikt begrippen in verschillende betekenissen. Ik denk dat de 'Long Arc of Transcendental Religion' van Szerszynski ons helpt om de visie van Latour scherp te krijgen.

Szerszynski stelt dat in het moderne denken de wereld volkomen profaan of seculier is en geen enkele spirituele betekenis heeft. In zijn visie presenteert het seculiere zich als een 'self-grounding, independent

9 Zie vorige noot. 
reality' (Szerszynski, 2005b, p. 816). Deze visie vinden we op twee wijzen terug in het denken van Latour. Enerzijds in zijn kritiek op de moderniteit die geen oog heeft gehad voor de Aarde als actor en die zich ten onrechte heeft laten meeslepen met het geloof in de vooruitgang. Vanuit dat perspectief kunnen we begrijpen dat Latour pleit voor een nieuw contrast tussen 'enerzijds de termen religieus of seculier en anderzijds de term aards' (curs. BL) (Latour, 2017, p. 298). Anderzijds in het ontvouwen van zijn eigen visie waarin hij Gaia presenteert als een proces zonder 'kader, doel of richting' (Latour, 2017, p. 157). Met deze uitspraak wil hij recht doen aan het Aardse als ruimte die alleen profaan is, die geen relatie (meer) heeft met het sacrale.

Een interessante vraag is of in het denken van Latour het sacrale inderdaad verdwenen is of dat er toch een herordening heeft plaatsgevonden. Ik ben van mening dat dat laatste het geval is. Het sacrale komt namelijk terug in de opvatting van Gaia als 'verbindingseffecten tussen handelingsvermogens' en als 'proces' 'zonder kader, doel of richting' (Latour, 2017, pp. 143, 157). Ik kan me niet onttrekken aan het gevoel dat het sacrale van Latour getekend is door een (gelukkige) spanning. Het is namelijk lastig om de woorden 'zonder kader, doel of richting' te laten sporen met zijn diepe betrokkenheid bij de grote vraagstukken en zijn morele verontwaardiging over de politieke elites die van elke pagina van zijn boeken afspat.

\section{Dans van de moderne mens}

Ik kom terug op de dans van Stéphanie Ganachaud. Op een gegeven ogenblik zie je dat ze langzaam tot stilstand komt, zich omdraait en terugdeinst. Er komt iets angstaanjagender op haar af dan datgene waarvoor ze is gevlucht. Latour (2017, p. 13) sluit af met de woorden: 'Door te vluchten voor iets gruwelijks, stuit ze op een andere gruwel die deels door haar vlucht is veroorzaakt.' Het gaat me om de woorden 'een andere gruwel die deels door haar vlucht is veroorzaakt.' Zoals we hebben gezien is die gruwel de Aarde die zich tegen de moderne mens keert; de moderne mens die zich laat leiden door de ratio, de natuurwetenschappelijke blik en de economie.

Om te begrijpen wat er precies gebeurt wil ik graag gebruik maken van het werk van de Nederlandse filosoof Herman Dooyeweerd. Dooyeweerd 
benadrukt - ik volg hier in grote lijnen zijn boek Vernieuwing en Bezinning - dat de culturele, wetenschappelijke en geestelijke ontwikkeling van de westerse cultuur in hoge mate beheerst wordt door religieuze motieven. Het woord 'religie' gebruikt Dooyeweerd hier in een brede betekenis: het gaat om de 'geestelijke drijfkracht' of diepste motieven van een cultuur. Om het fundamentele karakter van deze motieven te benadrukken spreekt hij van 'grondmotieven'. Dooyeweerd onderscheidt vier religieuze grondmotieven die in achtereenvolgende perioden in de geschiedenis hun stempel hebben gezet: het Griekse, het christelijke, het rooms-katholieke en het humanistische. Dooyeweerd wijst erop dat de opkomst van een nieuw grondmotief als 'leidende macht' niet betekent dat een voorgaand motief wordt uitgeschakeld, maar dat deze (tijdelijk) in het defensief wordt gedrongen. Met andere woorden, grondmotieven kunnen in de cultuur blijven doorwerken. Ik beperk me tot het humanistische grondmotief.

Dooyeweerd (1963, p. 146) stelt dat het humanistische of moderne grondmotief bestaat uit twee idealen die met elkaar strijden om de voorrang: het vrijheidsideaal en het beheersingsideaal. De ene keer overheerst het ene ideaal en de andere keer het andere. Het vrijheidsideaal vindt haar oorsprong in de Renaissance waarin de wedergeboorte van de nieuwe mens centraal staat. Dooyeweerd (1963, p. 144) schrijft: 'In de Renaissance gaat het ten diepste om een "wedergeboorte" van de mens in bloot natuurlijke zin. De "nieuwe tijd", die men zich bewust is in te gaan, eist een "vernieuwde mens" die zijn lot in eigen hand weet te houden en niet meer gelovig autoriteiten naspreekt' (curs. HD). De nieuwe mens treedt de natuur dan ook met een heel andere houding tegemoet. In negatieve zin gaat het om het beheersen van de krachten van de natuur die de menselijke vrijheid bedreigen en in positieve zin gaat het om het beheersen van de natuur als speelveld van de menselijke vrijheid. Dooyeweerd schrijft (1963, p. 145): 'De moderne mens, in zijn trots autonomie- en vrijheidsbesef, ziet de "natuur" als het grote exploratie-terrein voor de vrije persoonlijkheid, als een veld vol oneindige mogelijkheden, waarin zich de souvereiniteit der menselijke persoonlijkheid dient te openbaren, in een volledige beheersing van de natuurverschijnselen', curs. HD). Dooyeweerd (1963, p. 147) wijst er verder op dat (a) de beheersing plaatsvindt in de weg van de natuurwetenschappelijke denkwijze en (b) dat deze denkwijze een handvat biedt voor de beheersing van de gehele werkelijkheid. In de visie van Dooyeweerd (1963), p. 145) is 'het scheppingsmotief van de 
christelijke religie vervangen door het geloof in de scheppende kracht van het wetenschappelijke denken.'

Dooyeweerd (1963, pp. 146-150) stelt dat er een geweldige inherente spanning is tussen enerzijds het vrijheidsideaal en anderzijds het beheersingsideaal. Het vrijheidsideaal vraagt dat we de wereld om ons heen volledig beheersen: alleen dán kan de mens volkomen vrij zijn. Maar die beheersing beperkt zich niet tot onze natuurlijke leefomgeving, maar breidt zich uit tot de manier waarop mensen samenleven en tot de individuele mens zelf. Daarmee vormt het beheersingsideaal een bedreiging voor de vrijheid van de mens. Dooyeweerd (1963, p. 147) stelt dat het niet mogelijk is om beide idealen te verenigen, omdat ze allebei van 'religieuze en dus absolute aard' zijn (curs. HD). ${ }^{10}$

Latour oefent scherpe kritiek op de moderniteit. Hij is van mening dat de gruwel, die door de vlucht van de mens wordt veroorzaakt, ten diepste haar oorsprong vindt in het natuurwetenschappelijke ideaal van de beheersing van de werkelijkheid. Ik denk dat Dooyeweerd het met deze analyse eens zou zijn. Maar hij zou er graag wel iets aan willen toevoegen. Namelijk dat de moderne mens gedreven wordt door twee absolute idealen: het ideaal van de beheersing en het ideaal van de vrijheid. En dat deze idealen niet samen gaan. Voor Dooyeweerd is het onbestaanbaar dat vrijheid en beheersing absolute begrippen zijn. Integendeel, in zijn visie zijn het normatieve begrippen.

Graag wil ik iets meer zeggen over normativiteit in de filosofie van Dooyeweerd. Ik heb helaas niet de mogelijkheid om dit breed uit te werken." Ik beperk me tot twee theorieën die ons een kader en vocabulaire aanreiken om normativiteit in de werkelijkheid met het oog op duurzaamheid scherp te krijgen: de theorie van de modale aspecten en de theorie van de individualiteitsstructuren. De theorie van de modale aspecten laat zien dat er sprake is van verschillende soorten wetten en normen zijn. ${ }^{12}$ Onder andere:

- fysisch-chemische wetten

- biologische wetten

10 De spanning tussen het vrijheidsideaal en beheersingsideaal heeft o.a. Goudzwaard (1982) uitgewerkt voor de ontwikkeling van de economie en Schuurman (1998) voor de ontwikkeling van de techniek.

11 Voor een recente introductie zie Verkerk e.a. (2016).

12 In totaal onderscheidt Dooyeweerd vijftien verschillende modale aspecten en daarmee vijftien verschillende soorten wetten en normen. 
- machts- of beheersingsnormen

- sociale normen

- economische normen

- esthetische normen

- juridische normen

- morele norme

- religieuze normen

Latour laat zien dat de moderne mens zich met name laat leiden door fysisch-chemische en biologische wetten en door economische normen. In de visie van Dooyeweerd is er sprake van een sterke reductie of versmalling van de begrippen 'wet' en 'norm' of 'normativiteit'. Het gaat niet alleen om de duurzaamheid van onze ecologie: biologische duurzaamheid. Het gaat ook niet alleen om de duurzaamheid van onze economie: economische duurzaamheid. Maar het gaat ook om duurzaamheid in het uitoefenen van macht en invloed, duurzaamheid van sociale relaties, duurzaamheid op het gebied van recht en gerechtigheid, duurzaamheid in de zorg voor natuur en medemens, en duurzaamheid van hoop en vertrouwen. Het niet voldoen aan deze verschillende soorten wetten en normativiteiten met het oog op duurzaamheid leidt altijd tot instabiele situaties. Zo is bijvoorbeeld een maatschappij waarin macht en bezit sterk ongelijk verdeeld zijn niet duurzaam. Maar ook een maatschappij waarin sociale relaties en zorg voor de natuur en de medemens het af moeten leggen tegen de winstgevendheid van de grote bedrijven is niet duurzaam.

De theorie van de individualiteitsstructuren laat zien dat de samenleving uit een groot aantal verbanden bestaat die ieder een eigen karakter en daarmee een eigen normatieve structuur hebben. Dat eigen karakter wordt uitgedrukt met het woord 'kwalificerende functie'. De kwalificerende functie van een gezin is het morele aspect: het gaat om de zorg voor elkaar. De kwalificerende functie van de staat is het juridische aspect: het gaat om recht en gerechtigheid. De kwalificerende functie van respectievelijk een bedrijf, een gezelligheidsvereniging en een kerk is achtereenvolgens het economische, sociale en religieuze aspect. In de visie van Dooyeweerd bestaat een samenleving dus, naar een uitdrukking van Chaplin (2011, p. 110), uit een 'medley' van verschillende structuren. De theorie van de individualiteitsstructuren helpt ons om te begrijpen hoe de samenleving in elkaar zit: allerlei verschillende structuren die met elkaar interacteren en elkaar beïnvloeden. In een duurzame 
samenleving kunnen al deze verschillende structuren alleen bloeien als deze structuren zich 'naar hun eigen aard' kunnen ontwikkelen. In een gezin moet de zorg voor elkaar centraal blijven staan. In een onderneming gaat het om een waardevolle bijdrage aan de samenleving waarbij het maken van winst een randvoorwaarde is. En in de staat gaat het om het bevorderen van recht en gerechtigheid.

Ik kan het niet laten om een enkel woord te zeggen over de normatieve structuur van de universiteit. In mijn visie gaat het in een universiteit allereerst om een brede wetenschappelijke vorming van jonge mensen. Het gaat daarbij niet alleen om een grondige kennis van het eigen vakgebied maar ook om de sociale, morele en filosofische aspecten van dat vakgebied. ${ }^{13}$ In dit verband wil ik verwijzen naar een uitspraak die mijn collega Schurgers minder dan een jaar geleden op deze plek deed. Hij zei: 'Er is veel veranderd over de jaren. De oude universiteit als instituut sterft langzaam omdat de ivoren torens worden verlaten, doordat professoren managers worden en studenten consumenten. Geld is de maat der dingen, de universiteit is ondernemend geworden. En hoe graag we het zouden willen, het is onmogelijk dit proces te keren: het is namelijk niet de universiteit die is veranderd, het is een totale maatschappelijke verandering' (Schurgers, 2018, p. 25). Ik geloof er niets van dat de constatering van het 'sterven van de oude universiteit' en 'geld als maat der dingen' voor deze universiteit als geheel geldt. Zelfs als dat alleen voor bepaalde faculteiten of afdelingen zou gelden, dan zou ik verwacht hebben dat hij zich fel tegen deze trend gekeerd zou hebben. Het is namelijk deze visie - ik verwijs naar de analyses van Latour en Dooyeweerd - die mede ten grondslag ligt aan de huidige maatschappelijke problemen.

\section{De (politieke) elites en de overheid}

Latour is van mening dat de (politieke) elites niet goed voorgesorteerd zijn om de klimaatcrisis aan te pakken. Hij schrijft: 'Het drama is dat Gaia zich opdringt op het moment dat de mens slechter dan ooit lijkt aangepast om daarmee rekening te houden' (Latour, 2017, p. 157). lets

13 Ik denk daarbij aan het begrip 'Bildung' dat door de Duitse geleerde en diplomaat Wilhelm von Humboldt (1767-1835) gemunt is. Bij Bildung gaat het niet alleen om de vorming van zelfstandige denkers maar ook om de vorming van goede burgers met oog voor cultuur en samenleving. 
verderop lezen we: 'Net nu we weer aan politiek zouden moeten gaan doen, staan ons alleen nog de zielige hulpmiddelen "management" en "beleid" ter beschikking' (Latour, 2017, p. 158). Zoals al eerder gezegd, Latour is van mening dat het dromen van ontsnapping of het ontkennen van het probleem geen optie is. Hij schrijft: 'Het is onze enige uitweg: gezamenlijk ontdekken welk territorium bewoonbaar is en met wie we het moeten delen' (Latour, 2018, p. 20). Let even op de woorden 'gezamenlijk ontdekken', 'welk territorium bewoonbaar is' en 'met wie we het moeten delen'. In de visie van Latour komt er alleen 'weer ruimte voor politiek' door 'verdeling van handelingsvermogens' en 'keuze van onderlinge verbindingen tussen deze vormen van handelen' (Latour, 2017, p. 207). Met andere woorden, hij pleit voor een herverdeling van politieke macht en een herontwerp van politieke machtsstructuren.

Latour geeft geen expliciete visie op de overheid. Wel is duidelijk dat de eerde genoemde verschijnselen als de explosie van ongelijkheden, klimaatcrisis en de vluchtelingenstromen te maken hebben met de waarden rechtvaardigheid en gelijkheid. In de visie van Dooyeweerd vinden we spanning tussen het vrijheidsideaal en het beheersingsideaal ook terug in de verschillende visies op de overheid. In het liberale model van de staat domineert het vrijheidsideaal. De staat dient de vrijheid van elk individu mogelijk te maken en te beschermen. In deze benadering wordt geopteerd voor een 'minimale' staat. In het sociaaldemocratische model van de staat domineert het beheersingsideaal. De staat dient de vrijheid en de gelijkheid van alle burgers mogelijk te maken. In deze benadering heeft de overheid een uitgebreid takenpakket.

Dooyeweerd is van mening dat de staat een eigen normatieve structuur heeft. ${ }^{14}$ In zijn visie wordt dit structuur niet bepaald door waarden als vrijheid en gelijkheid maar door waarden als recht en gerechtigheid. De kwalificerende functie van de staat is het juridische aspect. Dat wil zeggen, elke staat behoort zich zowel nationaal als internationaal in haar handelen te laten leiden door de waarden recht en gerechtigheid. Dooyeweerd neemt daarmee een normatieve positie in. Recht heeft met name te maken met de juridische positie van burgers ten opzichte van de staat en ten opzichte van elkaar. Rechtvaardigheid is een begrip uit de politieke filosofie dat te maken heeft met de verdeling van rechten,

14 Chaplin (2011) geeft een goede analyse van de opvattingen van Dooyeweerd over de staat. Zie tevens Skillen (2014). 
vrijheden, sociale posities en economische welvaart. ${ }^{15}$ Het behoeft geen betoog dat in de visie van Dooyeweerd de staat zich opnieuw moet oriënteren in de huidige context die bepaald wordt door een toename van ongelijkheden, opwarming van de aarde, vluchtelingenstromen en opkomst van populistische partijen. Het gaat om het handhaven van de huidige wetten en het bevorderen van rechtvaardigheid door middel van internationale verdragen en wetgeving.

\section{Pleidooi voor het heilige}

In het voorgaande heb ik een analyse gegeven van het denken van Bruno Latour over de klimaatcrisis. Ik heb geprobeerd om aan de hand van het denken van Ferry, Szerszynski en Dooyeweerd deze analyse aan te vullen en te verdiepen. Zoals al eerder gezegd: ik ben diep onder de indruk van de betrokkenheid, het denkvermogen en de intellectuele moed van Bruno Latour.

Ik heb niet de illusie dat ik - staande op de schouders van grote filosofen - in een afscheidsrede de grote problemen van onze tijd in al hun scherpte en volledigheid kan typeren. Laat staan met antwoorden komen die de potentie in zich hebben om die problemen daadwerkelijk op te lossen. Wel wil ik - vanuit mijn eigen positie als wetenschappergehoor geven aan de oproep van Latour (2017, p. 110) om 'opnieuw aan politiek te doen.'

\section{Recht, gerechtigheid en vrede}

Ik begin met het vertellen van een verhaal uit de Joodse geschiedenis. $U$ kunt het vinden in Jeremia 22:13-16. Dit verhaal gaat over koning Jojakim van Juda. Deze koning regeerde in een politiek roerige periode. Het land moest forse belastingen betalen aan de farao van Egypte. Om deze schattingen op te kunnen brengen legde koning Jojakim het land zware belastingen op. Ondanks al zijn politieke en financiële problemen liet hij voor zichzelf een indrukwekkend paleis bouwen. Voor de afwerking gebruikte hij cederhout dat prachtig rood geverfd werd. Voor de realisatie van zijn paleis legde Jojakim het volk een 'herendienst' op: ze moesten de gebouwen maken zonder dat ze betaald werden.

15 Sandel (2010) geeft een heldere introductie tot het begrip 'gerechtigheid' in de politieke filosofie. 
Over deze koning zegt de profeet het volgende:

'Wee hem die zijn huis op onrechtvaardigheid bouwt, die de bovenvertrekken met onrecht schraagt, die anderen voor zich laat werken maar hun geen loon betaald, die zegt: "Ik bouw voor mezelf een indrukwekkend paleis, met ruime bovenvertrekken, vol vensters, bekleed met cederhoud, prachtig rood geverfd." Ben je koning door de pracht van je cederhout?' 'Je vader had aan niets gebrek. Recht en gerechtigheid handhaafde hij Hij leefde in voorspoed.

Hij beschermde het recht van armen en behoeftigen En hij leefde in voorspoed.

Is dat niet: mij kennen?

- Spreekt de Heer.'

In deze profetie vinden we twee vragen die de zaak op scherp stellen. De eerste vraag is: Ben je koning door de pracht van je cederhout? Met andere woorden: Wat is eigenlijk de kern van het koningschap? Om deze - retorische - vraag scherp te krijgen, verwijst de profeet naar de vader van koning Jojakim. De tekst zegt dat zijn vader, koning Josia, het recht en de gerechtigheid handhaafde en dat hij het recht van de armen en behoeftigen beschermde. Zo komt de profeet tot de tweede vraag: Is dat niet: mij kennen? Met andere woorden, als je mij, de God van Israël kent, dan weet je dat je geen koning bent in het etaleren van je rijkdom maar alleen koning kunt zijn in het handhaven van recht en gerechtigheid.

In het Oude Testament is het woord 'gerechtigheid' als eerste een juridisch begrip is. Het houdt in dat 'rechtgedaan wordt aan wie onrecht heeft geleden' (Pop, 1980, p. 237). Daarnaast zien we dat het doen van gerechtigheid direct verbonden wordt met het betonen van barmhartigheid aan de arme, de weduwe, de wees en de vreemdeling (van Leeuwen, z.j., pp.151-180). Ten slotte wordt het begrip gerechtigheid in het Oude Testament verbonden met vrede ('shalom'). Wolterstorff (1983, p. 69) schrijft: 'We shall see that shalom is intertwined with justice. In shalom, each person enjoys justice, enjoys his or her rights. There is no shalom without justice. But shalom goes beyond justice.' Hij vervolgt: 'Shalom is the human being dwelling at peace in all his or 
her relationships: with God, with self, with fellows, with nature.' Vrede in het Oude Testament omvat dus alle relaties van de mens: met God, met zichzelf, met de medemens en met de natuur! Wolterstorff (1983, pp. 71-72) schrijft dat de oudtestamentische profetieën over vrede en gerechtigheid vervuld zijn in Jezus Christus. ${ }^{16}$ Daarom is het ook een prachtige keuze dat Ferry juist de figuur van Jezus Christus naar voren haalt om het christendom te begrijpen en de betekenis daarvan voor de relaties van de mens te duiden.

\section{Ongemakkelijk actueel}

De rijkdom van het westen is gebouwd op onrecht en onrechtvaardigheid. Wat dat betreft is de profetie van Jeremia ongemakkelijk actueel. Dat ongemakkelijke geldt ook voor mijn eigen traditie. Het christendom is ook door de Verlichting gegaan en heeft een forse klap van de molen van de vooruitgang meegekregen. Christenen hebben, samen met humanisten, andere landen leeggeroofd om de eigen welvaart te kunnen betalen (Hösle, 1994). Christenen hebben zich verloren in rechtslinkse, liberaal-sociaaldemocratische of republikeins-democratische discussies en daarmee het eigene van de eigen traditie en belangrijke concepten en waarden uit de eigen traditie verwaarloosd. De schuld van het rijke westen wordt elk jaar, elke maand, elke week en elke dag groter. We zijn bezig de natuur onherstelbaar te beschadigen, het kapitaal komt in handen van steeds minder mensen, de sociale tegenstellingen nemen toe en de vluchtelingenstromen worden talrijker.

\section{De verborgen dimensie van de klimaatcrisis}

In mijn visie is er sprake van een verborgen dimensie in het debat over de klimaatcrisis. Een dimensie die niet aan de orde wordt gesteld, maar die wel stilzwijgend en onuitgesproken aanwezig is. Een dimensie die we vergeten zijn en verdrongen hebben. Die verborgen dimensie heeft te maken met de manier waarop wij met elkaar en met de natuur verbonden zijn. Onder invloed van de moderne wetenschap en technologie hebben we door onze rationele en objectiverende aanpak geen oog gehad voor de verbindingen van de mens - beter: we hebben geabstraheerd van die verbindingen - waardoor die verbindingen niet meer ter sprake kwamen. De verborgen dimensie wil ik dan ook omschrijven als 'verbroken verbindingen'.

16 Voor theologische reflecties over vrede en gerechtigheid in relatie tot duurzaamheid verwijs ik naar de encycliek Laudato Si'van Paus Franciscus en Groene theologie van Trees van Montfoort. 
In de wereld van management en organisatie wordt wel onderscheid gemaakt tussen de waarom-vraag, de hoe-vraag en de wat-vraag. Je begint met de waarom-vraag (Waarom is er een probleem?), dan de hoe-vraag aan de orde stelt (Hoe los je dat probleem op?), en als laatste de wat-vraag bespreekt (Wat ga je precies doen?). De gedachte is dat je eerst de waarom-vraag aan de orde moet stellen voordat je de hoe-vraag en de wat-vraag zinnig kunt beantwoorden.

Daarom is het zo belangrijk om de verborgen dimensie in het klimaatdebat expliciet te maken. Het gaat om de waarom-vraag waarmee het debat moet beginnen. Het antwoord op die waarom-vraag is: verbroken verbindingen.

\section{Religie, duurzaamheid en inclusie}

Ik vind het woord 'religieus' mooi. Het komt namelijk van 'religare'; 're-' is opnieuw en 'ligare' is verbinden. Het gaat dus om het 'opnieuw verbinden'. Dat wil zeggen, om het herstel van verbroken verbindingen. Ik weet dat sommige wetenschappers zich ongemakkelijk voelen bij het woord 'religie' en liever woorden gebruiken als 'wereldbeschouwing' of 'basisovertuigingen'. Wat mij betreft prima. Waar het mij hier om gaat is het belang van het opnieuw verbinden. Zonder verbindingen kunnen we namelijk nooit samen ontdekken waar we kunnen landen en met wie we de plek waar we landen moeten delen. Het is een illusie te menen dat verbroken verbindingen - onafhankelijk van de vraag of ze een christelijke of moderne achtergrond hebben - in de weg van technische oplossingen, beleidsvisies en implementatie strategieën hersteld worden. Daar is meer voor nodig: verbinding met datgene wat boven mijn individuele bestaan uitstijgt. Het gaat dan om de relatie met de natuur (duurzaamheid) en de relatie met de medemens (inclusie). Als ik de analyses van Ferry en Szerszynski over onze postmoderne samenleving serieus neem, dan ligt er een geweldige uitdaging om opnieuw verbinding te leggen tussen mens en natuur en tussen mensen onderling. De klimaatprotesten van jongeren zouden weleens een teken van hoop kunnen zijn.

In dit verband wil ik extra aandacht geven aan het woord 'inclusie'. In het hele klimaatdebat klinkt de angst door dat alleen de (politieke) elites en het internationale bedrijfsleven zullen profiteren van de energietransitie. Ik denk dat deze angst - vriendelijk uitgedrukt - niet onterecht is. Het is mijn diepe overtuiging dat de energietransitie alleen kan slagen als we verbindingen herstellen: tussen rijke en arme landen, tussen rijke en arme mensen in rijke landen, en tussen rijke en arme mensen in arme 
landen. Het behoeft geen toelichting dat in het uitspreken van die diepe overtuiging de waarden 'vrede','gerechtigheid' en 'recht' mede resoneren.

Een mogelijke tegenwerping zou kunnen zijn dat een beroep op religie, wereldbeschouwing of basisovertuigingen niet leidt tot verbindingen maar tot het verscherpen van tegenstellingen. Dat is waar. Daar is - in het algemeen gesproken - ook mijn eigen traditie debet aan. Maar ik wil er op wijzen dat een beroep op religie, levensbeschouwing of basisovertuigingen ook een bron van motivatie kan zijn om de verbindingen te zoeken en daadwerkelijk te leggen.

\section{Een pleidooi voor het heilige}

Misschien zijn deze woorden wel de lastigste woorden van de titel van mijn rede. Ik doe even een stapje terug. Op basis van het werk van de filosoof Luc Ferry heb ik de verborgen dimensie gekarakteriseerd als 'verbroken verbindingen'. Uit de analyse van Bronislaw Szerszynski blijkt dat deze verborgen dimensie een 'diepere laag' kent: het heilige. Het heilige stijgt boven mijn individuele bestaan uit: het is transcendent of Transcendent. Het heilige verbindt mij met de ander en met de natuur. In rituelen vieren we verbondenheid. Ik wil het verborgen of verzwegen heilige weer opnieuw ter sprake brengen. Het heilige in een religieuze of in een seculiere gestalte.

Ik begin met mijn eigen traditie: de christelijke traditie. Latour (2017, p. 296) oefent scherpe kritiek uit op christenen. Hij prikkelt ze door de beroemde evangelische aanmaning uit Matteüs 16:26 in een omgekeerde vorm aan christenen voorgehouden moet worden: 'Wat heeft een mens eraan als hij zijn ziel wint maar er de wereld bij inschiet' (Latour, 2017, p. 297). Ik voel me aangesproken door zijn kritiek. Als christenen zijn we vergeten dat het seculiere betekenis krijgt vanuit het heilige. Met andere woorden, de mens, de wereld of de natuur krijgt betekenis vanuit het geloof in Jezus Christus. Dat komt scherp naar voren in de woorden van de apostel Paulus in de brief aan de Kolossenzen (1:16-20):

\footnotetext{
'in hem (Jezus Christus, MJV) is alles geschapen, alles in de hemel en alles op aarde (...) alles is door hem en voor hem geschapen. Hij bestaat vóór alles en alles bestaat in hem (...) en door hem en voor hem alles met zich willen verzoenen, alles op aarde en alles in de hemel (...).
} 
Met andere woorden, de verbinding met de Heilige (Jezus Christus) ligt ten grondslag aan de verbindingen met de medemens en met de natuur.

Ook in gesprek met de moderne traditie wil ik het verborgen of verzwegen heilige aan de orde stellen. ${ }^{77}$ De analyse van Szerszynski maakt duidelijk dat het moderne denken niet leidt tot het verdwijnen van het heilige maar tot een herordening van het heilige. Als ik Latour goed begrepen heb, dan komt dat heilige tot uitdrukking in 'wederzijdse verbindingen' en 'verbindingseffecten tussen handelingsvermogens'. Ik zou dat expliciet willen maken: het gaat om verbindingen met de medemens en met de natuur.

Ik kom terug op de dans van Stéphanie Ganachaud. Een dans vol betekenissen. Eén betekenis is de notie van schuld. Deze notie komt ook naar voren in een gesprek tussen Luc Ferry met Marcel Gauchet over de toekomst van religie. Hierin stelt Ferry dat offeren een essentieel element van het heilige is (Ferry \& Gauchet, 2008, p. 72). Hij wijst er op dat die verbinding mooi tot uitdrukking komt in de Franse taal: het heilige is 'le sacré' en het offer 'le sacrifice'. Het kan niet anders dan dat onze klimaatschuld grote offers zal vergen. Het gaat ons misschien wel - om een gevleugelde uitdrukking te gebruiken - duizend miljard Euro kosten. Een andere betekenis is die van strijd. Latour voorziet dat de klimaatcrisis - beter: de herverdeling van handelingsvermogens gepaard zal gaan met strijd, veel strijd. Hij schrijft: 'Als Gaia kon spreken, zou ze net als Jezus zeggen: "Denk niet dat ik gekomen ben om op aarde vrede te brengen. Ik ben niet gekomen om vrede te brengen, maar het zwaard"' (Latour, 2017, p. 208). Die strijd zien we terug in de samenleving (protesten van de 'gele hesjes', protesten van jongeren, in de activiteiten van de 'merchants of doubts') en in de politiek (populisme).

\section{Dankwoord}

Voor u staat een dankbaar mens. Een mens die met velen verbonden is. Het is geweldig om onderwijs te geven. Ik heb er werkelijk elke dag van genoten. Ik zal dat missen. Het was ook geweldig om, vaak samen met anderen, onderzoek te doen. Gelukkig kan ik daar nog even mee doorgaan.

17 Ik gebruik de woorden 'moderne traditie' in Latouriaanse zin: Latour maakt geen onderscheid tussen het moderne en postmoderne denken. 
Allereerst dank ik het bestuur en de curatoren van de Stichting voor Christelijke Filosofie. Met plezier kijk ik terug op onze samenwerking. Ik heb het altijd als een eer ervaren om de leerstoelen in Eindhoven en Maastricht te bekleden. Ik ben ook dankbaar voor alles wat ik in de Stichting voor Christelijke Filosofie heb ontvangen. Dat heeft voor altijd een stempel op mij gezet. Ik herinner me nog hoe ik als jong student - ik was 19 jaar - de eerste colleges reformatorische wijsbegeerte bij professor Klaas Popma volgde. Ik moet eerlijk zeggen: zijn eruditie en mijn ontluikende filosofische interesse was een bijzondere combinatie. Het eerste wat ik leerde was dat filosofie wel heel moeilijk was. Maar veel belangrijker: ik leerde het belang van filosofische reflectie. Zijn opvolger, professor Jan Dengerink was een heel andere persoonlijkheid. Hij was een goed docent en heeft mij echt enthousiast gemaakt voor de christelijke filosofie. Daarnaast zijn er veel andere hoogleraren in de beweging geweest die een grote invloed op mijn ontwikkeling hebben gehad. Ik noem er slechts één: Egbert Schuurman die mijn tweede proefschrift hebben begeleid. Ook dank ik de leden van centrum voor al het werk 'achter de schermen'.

Ik dank de Faculteit Cultuur- en Maatschappijwetenschappen van de Universiteit Maastricht en de Faculteit Industrial Engineering \& Innovation Sciences van de Technische Universiteit Eindhoven voor de ruimte die ik heb gekregen om onderwijs te geven en onderzoek te doen. Het was altijd een waar genoegen om uw midden te verkeren. Ook dank ik de lokale curatoria voor de steun en bemoediging.

Ik dank de studenten voor hun inzet en enthousiasme. Met veel genoegen kijk ik terug op de intensieve discussies die we met elkaar hebben gehad over film en filosofie, techniek en ethiek, filosofie en religie, verborgen vooronderstellingen in de wetenschap, maatschappelijke verantwoordelijkheden en levensvragen. Ik kan me sommige gesprekken nog haast woordelijk herinneren. Zoveel indruk hebben ze op me gemaakt. Ook was en is het een voorrecht om promovendi te begeleiden.

Ik dank ook mijn (ex-) collega-hoogleraren Christelijke Filosofie. Elke keer was het geweldig om in jullie midden te zijn. Wat heb ik veel van jullie geleerd! Met plezier kijk ik terug op de filosofische discussies, de gesprekken over existentiële vragen en de vele gezellige momenten. 
Het is een voorrecht om veel familie, buren en vrienden te hebben. Fijn dat jullie er vanmiddag ook bij zijn.

Last but not least wil ik mijn gezin noemen. Ik begin met mijn kinderen, schoondochters en schoonzoon. Remme en Femmie, Jaapjan en Roeliene, Marc en Leila, Marianne en Pieter, ik vind het prachtig om te zien hoe jullie voor elkaar zorgen, voor anderen zorgen en ook je eigen plekje in de samenleving hebt gevonden. Ik ben hartstikke trots op jullie. Het is ook prachtig om kleinkinderen te hebben: Lucas, Thijs, Luc, Bram en Fien. In het bijzonder wil ik ook Nienke, mijn vrouw, bedanken. Voor het denkwerk dat we samen hebben gedaan. Voor je liefde en je zorg. Niet elke wetenschappelijke of populairwetenschappelijke publicatie die ik geschreven heb ik, is mij in dank afgenomen. Daar heb jij ook last van gehad. Fijn dat je altijd achter me stond.

Ik kom terug op de vraag die Graham Greene in het begin van zijn boek Het einde van het spel oproept. Kiest een schrijver uit vrije wil een beeld of kiest het beeld de schrijver? Ik heb bij het schrijven van deze afscheidsrede regelmatig aan deze vraag moeten terugdenken. De moderne wetenschapper in mij - ik heb $\mathrm{u}$ beloofd dat ik hierop terug zou komen - is geneigd om voor de eerste optie te gaan: de schrijver kiest uit vrije wil het beeld dat hij nodig heeft. Maar de filosoof en de politicus in mij protesteren. Dat protest heeft te maken met de verbindingen die ik heb. Ik voel me verbonden met de profeet Jeremia. Ik voel me verbonden met Jezus Christus. Het zou zo maar kunnen zijn dat de waarden die zij symboliseren - recht, gerechtigheid en vrede - mij gekozen hebben. Het zou ook zo maar kunnen zijn dat die waarden mij zo in bezit hebben genomen, dat ik de klimaatcrisis in deze afscheidsrede wel aan de orde moest stellen.

Ik heb gezegd. 


\section{Excurs: Klimaatwetenschap en klimaatontkenning}

Is er wel sprake van een klimaatcrisis? Zouden we niet veel meer moeten luisteren naar de argumenten van de klimaatontkenners? Wetenschappelijke feiten en theorieën moeten toch kritisch bevraagd worden? En, voordat we vele miljarden gaan uitgeven - sommige politici zeggen dat het Nederland wel meer dan duizend miljard Euro gaat kosten - zou het niet wijs zijn om met elkaar in debat te gaan over de feiten? In mijn visie zijn dit 'eerlijke vragen'. Dat wil zeggen, het zijn vragen die in het debat over de klimaatcrisis gesteld mogen worden en die om een antwoord vragen.

Ik beperk me tot drie punten:

1. Wat is de stand van zaken in de wetenschap?

2. Hoe komt het dat er wetenschappers zijn met een afwijkende mening?

3. Hoe komt het dat klimaatontkenners zo sterk aan de weg timmeren?

\section{Wat is de stand van zaken in de wetenschap?}

De eerlijkheid gebied te zeggen dat in de wetenschap de grote discussies over het al dan niet opwarmen van de aarde al beëindigd zijn. Aan het einde van de tachtiger jaren van de vorige eeuw groeide het inzicht dat de aarde aan het opwarmen was ten gevolge van de zogenaamde broeikasgassen. In 1995 publiceerde het Intergovernmental Panel on Climate Change (IPCC) het rapport Climate Change 1995: The Science of Climate Change waarin ondubbelzinnig werd geconcludeerd dat de opwarming van de aarde werd veroorzaakt door broeikasgassen die het gevolg waren van menselijke activiteiten. Dit rapport werd door honderden wetenschappers uit verschillende landen en van verschillende universiteiten onderschreven..$^{18}$ Latere rapporten van het IPCC bevestigden deze conclusies.

Vanaf pakweg 2010 is er in de klimaatwetenschap een brede consensus dat (1) de aarde opwarmt en (2) dit een gevolg is van menselijke activiteiten. Dit blijkt onder andere uit het artikel van John Cook en

18 In de Troonrede van 1997 waarschuwde het kabinet voor de eerste keer tegen de stijging van de uitstoot van broeikasgassen: 'Nog steeds leidt meer economische groei tot een hogere Co2emissie. Hierin mogen we niet berusten, omdat de gevolgen voor het klimaat te ernstig zijn. Het is nodig om wereldwijd de uitstoot van broeikasgassen terug te dringen.' Zie http://www. troonredes.nl/troonrede-16-september-1997/ 
anderen (2013) naar de opvattingen van wetenschappers die actief waren in dit gebied. Maar liefst $97 \%$ van de wetenschappers stemden in met de conclusie dat de aarde opwarmt ten gevolge van de activiteiten van de mens. Later is dit onderzoek door Verheggen en anderen (2014) en een vervolgartikel van John Cook en anderen (2016) bevestigd. Voor een recent overzicht van de wetenschappelijke argumentatie, de weerlegging van de belangrijkste argumenten van klimaatontkenners en mogelijke oplossingen verwijs ik naar Maslin (2014). Een bredere analyse van de oorzaken geeft onder andere Bonneuil and Fressoz (2017).

Er is ook onderzoek gedaan naar de opvattingen van de Nederlandse bevolking over de verandering van het klimaat. Van Dalen en Henkens (2019) hebben laten zien dat het aantal Nederlanders dat zich in de periode 2009-2018 zorgen maakte over het klimaat steeg van $36 \%$ tot $58 \%$. Het aantal Nederlanders dat vindt dat de verhalen over de opwarming van de aarde overdreven zijn, daalde in deze periode van $24 \%$ tot $11 \%$. Ook is er gekeken naar politieke voorkeuren. Het aantal kiezers dat sceptisch is over klimaatberichten is bij de PVV het hoogst: circa 20 $\%$. In 2009 was dit nog circa $45 \%$.

\section{Hoe komt het dat er wetenschappers zijn met een afwijkende mening?}

Wetenschap is een menselijke activiteit. Je vindt wetenschappers in allerlei soorten en maten. Maar vooral: wetenschappers zijn kritisch. In wetenschappelijke tijdschriften en op wetenschappelijke congressen zijn levende debatten over feiten en theorieën. Zo werkt wetenschap en zo komt wetenschap ook verder. Een eerste verklaring voor het feit dat er wetenschappers met een andere mening zijn, geeft Latour (2018, pp. 80-81) zelf. Hij zegt dat wetenschappers op verschillende manieren wetenschap bedrijven. Sommigen kijken met een objectieve en rationele blik naar het klimaat en anderen met een gevoelige en betrokken blik. Dit verschil in attitude verklaart het verschil in visie op de verandering van het klimaat, de rol van de mens daarin, en de te nemen maatregelen.

Een andere mogelijke verklaring zou kunnen volgen uit het werk van de socioloog Thomas Kuhn. Kuhn (1996) heeft onderzoek gedaan naar de wijze waarop de wetenschap werkt. Hij heeft laten zien dat er tijden zijn van 'gewone wetenschap' en tijden van 'wetenschappelijke revoluties'. In tijden van gewone wetenschap zijn de wetenschappers het eens over de belangrijkste theorieën en de feiten die deze theorieën onderbouwen. 
Maar in tijden van revolutie zijn er veel feiten die niet meer met de oude theorie verklaard kunnen worden. Met als gevolg dat er nieuwe theorieën ontwikkeld worden om de afwijkende feiten te kunnen begrijpen. Na verloop van tijd ontstaat er weer opnieuw consensus: de oude theorie wordt verworpen en de nieuwe theorie is de standaard. Een voorbeeld van zo'n revolutie is de opkomst van de kwantummechanica in het begin van de $20^{\text {ste }}$ eeuw. De 'oude' theorieën van Newton konden een aantal verschijnselen niet meer verklaren. Maar die verschijnselen konden wel verklaard worden met behulp van de kwantummechanica. Uiteindelijk gingen (vrijwel) alle wetenschappers 'om' en werd de kwantummechanica de standaard voor de beschrijving van allerlei processen op atomair niveau. Kuhn (1996) laat ook zien dat ondanks het succes van de nieuwe theorie er altijd wetenschappers zijn die aan de oude theorie blijven vasthouden. Sommigen omdat ze nog niet overtuigd zijn van de nieuwe theorie of van het feitenmateriaal dat de nieuwe theorie ondersteunt. Anderen blijven 'gewoon' vasthouden aan de opvattingen waarmee ze zijn opgegroeid. Met andere woorden, het is een normaal verschijnsel in de wetenschap dat bij grote veranderingen in visie ('revoluties') er altijd een kleine minderheid is die de oude theorie blijft aanhangen. Dit fenomeen zou wel eens een verklaring kunnen geven waarom en klein percentage van de wetenschappers (3 \%) niet instemt met de conclusie dat de aarde opwarmt ten gevolge van de activiteiten van de mens.

Ten slotte, hoe komt het dat klimaatontkenners zo sterk aan de weg timmeren? Het antwoord is eenvoudig: er zijn groepen die belang hebben bij de ontkenning van de klimaatproblematiek. Zo is het bekend dat de oliemaatschappij Exxon Mobil, die uitermate goed op de hoogte was van de klimaatverandering en de gevaren daarvan, in het begin van de jaren negentig besloot om zwaar te investeren in een campagne die de stelling zou moeten promoten dat er geen sprake is van een dreigend gevaar. De reden voor die campagne was eigenbelang: haar commerciële belangen veilig stellen (Latour, 2018, p. 30). Een ander voorbeeld. Frank Luntz, een republikeinse strateeg in Amerika, erkende in een interview dat de wetenschap toegroeide naar een volledige consensus was over de klimaatverandering. Om te voorkomen dat er onrust onder de bevolking zou komen en dat die onmiddellijke maatregelen zou eisen, adviseerde hij om te doen alsof de bewijzen niet steekhoudend zijn (Latour, 2017, p. 45-46). Latour vat deze strategie als volgt samen: 'Het beschrijven van feiten staat zo gevaarlijk dicht bij het voorschrijven van een specifiek 
beleid dat er, om een einde te maken aan het ter discussiestellen van de industriële levenswijze, twijfel moet worden gezaaid over de feiten als zodanig' (curc. BL) (Latour, 2017, p. 46).

Oreskes en Conway (2010) hebben het fenomeen 'ontkenning' onderzocht in hun boek Merchants of Doubt. How a handful of scientists obscured the truth on issues from tobacco smoke to global warming. Zij laten zien dat er bij belangrijke issues altijd maatschappelijke partijen zijn die belang hebben van het ontkennen van fenomenen als bijvoorbeeld de schadelijkheid van het roken en de opwarming van de aarde. Zij brengen ook de strategie van die partijen in kaart: vraag naar de feiten, vergroot bestaande onzekerheden uit, poneer dat de dreiging is gebaseerd op modellen en niet op feiten, benadruk verschil van mening tussen wetenschappers, beschuldig wetenschappers van politieke motieven, enzovoorts. Zij stellen drie samenhangende vragen aan (semi-) wetenschappers in dit circuit: Wie vertegenwoordigt $u$, voor wie vecht $u$ en door wie wordt $u$ betaald?

Juist als het over het klimaat gaat - de sirenes loeien oorverdovend - kom ik op voor de wetenschappelijke instituties die 'gewoon' hun werk doen en die beseffen dat feiten ook een moreel aspect hebben. Het ongefundeerd aanvallen van en ongegrond twijfel zaaien over de integriteit van wetenschappers, wetenschappelijke instituten en universiteiten is onacceptabel. 


\section{Literatuur}

Baudet, Th. (2019). Spreektekst verkiezingsavond 20 maart 2019. https:// www.trouw.nl/nieuws/spreektekst-thierry-baudet-verkiezingsavond-20maart-2019

Bonneuil, C. \& Frezzos, J.P. (2017). The Shock of the Anthropocene. London: Verso.

Chaplin, J. (2011). Herman Dooyeweerd. Christian Philosopher of State and Civil Society. Notredame (IN): Notredame University Press.

Cook, J., Nuccitelli, D., Green, S.A., Richardson, M., Winkler, B., Painting, R., Wau, R., Jacobs, P. \& Skuce, A. (2013). Quantifying the consensus on anthropogenic global warming in the scientific literature. Environmental Research Letters, vol. 8, 7 pp. DOI:10.1088/1748-9326/8/2/024024.

Cook, J., Oreskes, N., Doran, P.T., Anderess, W.R.L., Verheggen, B., Maibach, E.W., Carlton, J.S., Lewandowsky, Skuce, A., Green, S.A., Nuccitelli, D., Jacobs, P., Richardson, M., Winkler, B., Painting, R. \& Rice, K. (2016). Consensus on consensus: a synthesis of consensus estimates on human-caused global warming. Environmental Research Letters, vol. 11, 7 pp. DOI:10.1088/17489326/11/4/048002.

Dalen, H.P. \& Renkens, K. (2019). Het veranderde klimaat over klimaatverandering. Demos: bulletin over bevolking en samenleving, vol. 35, nr. 4, pp. 1-4.

Dooyeweerd,H.(1941).Devier religieuzegrondthema'sindeontwikkelingsgang van het wijsgerig denken van het avondland. Philosophia Reformata, vol. 4, nr. 2, p. 161-179. Dit artikel is ook opgenomen in Verburg (1986).

Dooyeweerd, H. (1963). Vernieuwing en Bezinning. Om het reformatorisch grondmotief. Zutphen: Van den Brink.

Ferry, L. (2007). Beginnen met filosofie. Met andere ogen naar je leven kijken. Amsterdam: Arbeiderspers.

Ferry, L. \& Gauchet, M. (2008). Religie na de religie. Gesprekken over de toekomst van het religieuze. Kampen: Klement.

Goudzwaard, B. (1982, $4^{\text {de }}$ druk). Kapitalisme en vooruitgang. Assen: Van Gorkum.

Greene, G. (2003, $2^{\text {de }}$ druk). Het einde van het spel. Pandora Pockets. Vertaling van: The End of the Affair (1951).

Hösle, V. $(1994,2$.$) . Philosophie der ökologischen Krise. Moskauer Vorträge.$ München: C.H. Beck.

Kuhn, T.S. (1996, $3^{\text {rd }}$ ed.). The Structure of Scientific Revolutions. Chicago: University of Chicago Press. 
Latour, B. (2017). Oog in oog met Gaia. Acht lezingen over het Nieuwe Klimaatregime. Octavo.

Latour, B. (2018). Waar kunnen we landen? Politieke oriëntatie in het Nieuwe Klimaatregime. Octavo.

Leeuwen, C. van (z.j.). Sociaal besef in Israël. Baarn: Bosch \& Keuning.

Maslin, M. (2014. $3^{\text {rd }}$ ed.). Climate Change. A Very Short Introduction. Oxford: Oxford University Press.

Montfoort, T. van (2019). Groene theologie. Middelburg: Skandalon.

Oreskes, N. (2010). Merchants of Doubt. How a handful of scientists obscured the truth on issues from tobacco smoke to global warming. London: Bloomsbury.

Paus Franciscus (2015). Laudato Si'. Encycliek van Paus Franciscus over de zorg voor het gemeenschappelijke huis. Utrecht: Libertas Pascal.

Pop, F.J. (1980, 6 de druk). Bijbelse woorden en hun geheim. 's Gravenhage: Boekencentrum.

Sandel, M.J. (2010). Justice. What's the right thing to do?. London: Penguin.

Schurgers, L. J. (2018). Vasculaire verkalking: een hardnekkig probleem. Maastricht University. https://doi.org/10.26481/spe.20181012ls.

Schuurman, E. (1998). Geloven in wetenschap en techniek. Hoop voor de toekomst. Amsterdam: Buijten \& Schipperheijn.

Skillen, J.W. (2014). The good of politics. A biblical, historical, and contemporary introduction. Grand Rapids (MI): Baker.

Szerszynski, B. (2005a). Nature, Technology and the Sacred. Malden: Blackwell. Szerszynski, B. (2005b). Rethinking the Secular: Science, Technology, and Religion Today. Zygon, vol. 40, nr., pp. 813-822.

Verburg, M. (1986). Herman Dooyeweerd. Grenzen van het theoretisch denken. Baarn: Ambo.

Verheggen, B., Strengers, B., Cook, J., Dorland, R. van, Vringer, K., Peters, J., Visser, H. \& Meyer, L. (2014). Scientists' Views about Attribution of Global Warming. Environmental Science \& Technology, vol. 48, pp. 8963-8971. DOI: 10.1021/es501998e.

White, L. (1967). The Historical Roots of Our Ecological Crisis. Science, vol. 155, nr. 3767, pp. 1203-1207).

Verkerk, M.J. (2010). Herordening van het sacrale. Religie, ethiek en innovatie. Oratie Universiteit Maastricht.

Verkerk, M.J., Hoogland, J., Stoep, J. van der \& Vries, M.J. de (2016). Philosophy of Technology. An Introduction for Technology and Business Students. London: Routledge.

Wolterstorff, N. (1983). Until Justice \& Peace Embrace. Grand Rapids: Eerdmans. 
